Department of Zoology,

Fac. of Science, Assiut University,

Head of Dept. Prof. Dr.

\title{
INTRA-AND INTER-SPECIFIC VARIATIONS IN THE MERISTIC CHARACTERISTICS OF SOME TILAPIINE SPECIES OF EGYPT.
}

(With 11 Tables and 3 Figures)

\author{
By \\ I. A. A. MEKKAWY \\ (Received at 25/6/1995)
}

التبايثات النوعية وبين النوعية فى الخصائص العددية لبعض انواع البلطى من مصر

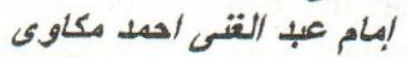

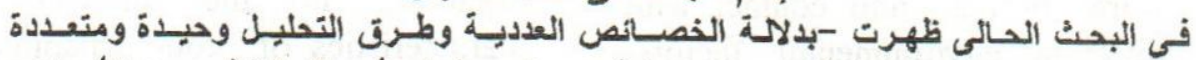

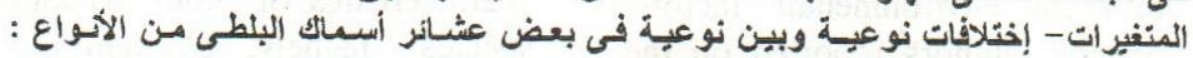

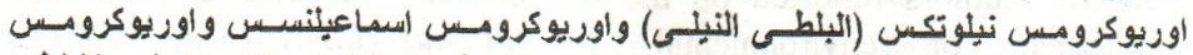

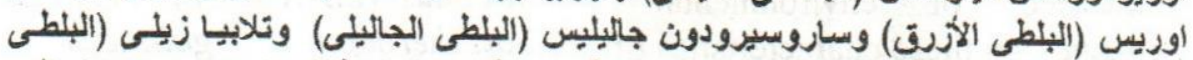

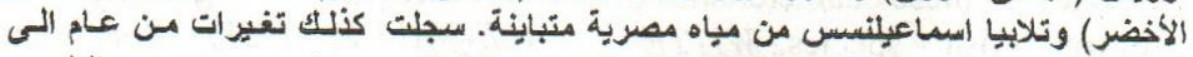

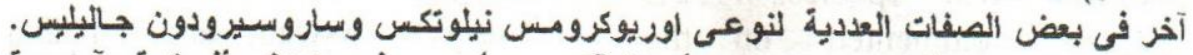

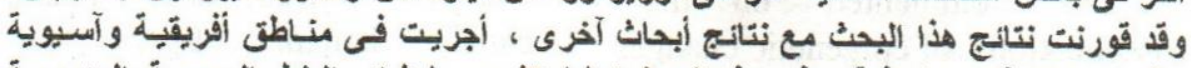

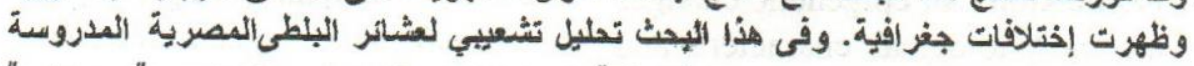

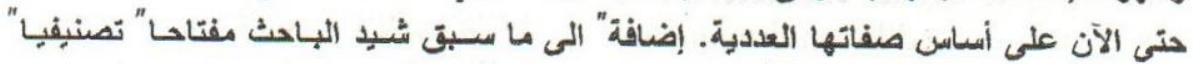
لتعريف أنواع البلطى المدروسة في مضر .

\section{SUMMARY}

In the present work, intra- and inter-specific variations of Oreochromis niloticus, O. ismailiaensis, O. aureus, Sarotherodon galilaeus, Tilapia Zillii, and T. ismailiaensis from different Egyptian waters were revealed in terms of their meristic characteristics by univariate and multivariate analyses. Year-to-year variations were recorded with respect to some meristic characters of Oreochromis niloticus and Sarotherodon galilaeus. The present results were compared with those of other authors working in different African and Asian regions. Clustering of populations of the species considered was given. Moreover, a key for identification of such populations was built up. Keywords: Intraspecific variations, interspecific variations, meristic characteristics, tilapiine species, Egypt. 


\section{INTRODUCTION}

Several species of the family Cichlidae have become popular with aquaculturists and aquarists (TREWAVAS, 1982) and were accordingly introduced into many tropical and subtropical countries of the world McANDREW and $M A J U M B A R, 1984)$. This possibly led to changes in their morphometric and meristic characteristics because the fish were brought into contact with different environmental factors. Several authors reported on the influence of environmental changes on these characteristics of several fish species. WITTE (1984) commented on the implications of epigenetic changes (of morphological characters and behavior caused by environmental factors) on the morphology and taxonomy of cichlids. Qualitative characteristics such as color, as well as morphometric measurements are often used in the identification and classification of fishes, although one seldom finds identical individuals in populations due to the occurrence of morphological, physiological and biochemical differences (MOYLE and CECH, 1982). Therefore, the identification of taxa and cultured stock, is central to aquaculture and effective fishery management of Tilapias.
This situation and the frequent changes due to eutrophication and pollution in our Egyptian lakes (BELTAGY, 1985; EL-OTIFY, 1985; ELEWA and AZAZY, 1986; SAMAAN and ABDELMONEIM, 1986) give rise to the present work. In a univariate and multivariate sense, this work is an attempt to determine the patterns of intra- and inter-specific variations in the meristic characteristics of four tilapiine species namely: Oreochromis niloticus (LINNAEUS, 1758) and Sarotherodon galilaeus (LINNAEUS, 1758) from Lake Nasser, Aswan, and Ismailia canal, Ismailia, Egypt and Oreochromis ismailiaensis MEKKAWY 1995 and Tilapia Zillii (Gerv.) from Ismailia canal, Ismailia. Moreover, the results of the present investigation will be compared with those of BISHARA (1973), SALEH (1980), TREWAVAS (1983), LIBOSVARSKY and BISHARA (1987) and MEKKAWY $(1995 a, b)$ to elucidate geographical variations in Egyptian (Fig.1), African and Asian populations of the species considered.

\section{MATERIAL and METHODS}

The present work, in December, 1989 - July 1993 period, was 


\section{I.A.A. MEKKEWY}

based on the examination of 807 specimens of O.niloticus (722 specimens from Lake Nasser, Aswan, $90-600 \mathrm{~mm}$ in total length (TL) \& 85 specimens from Ismailia canal, Ismailia, 133-170 $\mathrm{mm}$ in TL); 1978 specimens of S.galilaeus (1878 specimens from Lake Nasser, $130-440 \mathrm{~mm}$ in TL \& 100 specimens from Ismailia canal, 113-186 $\mathrm{mm}$ in TL); 56 specimens of T. Zillii (103-155 $\mathrm{mm}$ in TL) and 99 specimens of $O$. ismailiaensis (108-191 $\mathrm{mm}$ in TL) from Ismailia canal. The following meristic counts were studied; since each of the aforementioned species has discontinuous lateral line (upper portion and lower one); the pored scales and the unpored ones on their extension, anteriorly or posteriorly, were considered including those on the caudal fin.

1. Upper pored lateral line scale counts (UPLLS).

2. Upper unpored lateral line scale counts (UULLS).

3. Total upper lateral line scale counts (TULLS).

4. Lower pored lateral line scale counts (LPLLS).

5. Lower unpored lateral line scale counts (LULLS).

6. Total lower lateral line scale counts (TLLLS).

7. Caudal peduncle scale counts (CPS).

8. Soft rays of anal fin (AFSR).

9. Dorsal fin spines (DFS).

10. Soft rays of dorsal fin (DFSR).
11. Total dorsal fin rays (TDFR).

12. Total gill rakers on the first gill arch (TGR).

13. Precaudal vertebral counts (PCV).

14. Caudal vertebral counts (CV).

15. Total vertebral counts (TV).

16. Vertebral formula (VF).

The basic statistics (Frequencies, means (x) \& standard deviations (SD) were given for the meristic characters considered. Such characters were subjected to chisquare test to detect intra- and inter-specific variations at $0.05 \&$ 0.01 level of significance. The correlation coefficients between the meristic characters and standard length were insignificant at 0.05 level and, therefore, were omitted here.

The meristic characters were also treated by canonical variates analysis (CVA) using BLACKITH and REYMENT'S (1971) program and by sheared principal components analysis (PCA) (HUMPHRIES et al., 1981) using $M E K K A W Y ' S$ (1987) program to detect these variations in a multivariate sense. The Egyptian populations of the species considered were subjected to weighted pair group method cluster analysis (DAVIS, 1973) in terms of Euclidian distance matrix of the meristic characters studied.

\section{RESULTS}

Meristic characters of Oreochromis niloticus, O.ismailiaensis, 
Sarotherodon galilaeus \& Tilapia zillii are summarized in Table 1 in terms of their frequency distributions. Such a table refers to wide ranges for most meristic counts of tilapiine species considered; such wide ranges were due to their prolonged spawning periods. Chisquare analyses referred to the presence of few sexual variations in Oreochromis niloticus, O.ismaili-aensis, and Sarotherodon gali-laeus; no sexual dimorphism was recorded in Tilapia zillii (Table 2).

During the whole period of investigations, Geographic variations in the distributions of upper pored lateral line scale, dorsal fin spine, dorsal fin soft ray, total dorsal fin ray, anal fin ray, total gill raker and total vertebral counts of O.niloticus and S.galilaeus were recorded. These characters were also valuable in elucidating the interspecific differences in their distributions (Table 2).

Examination of the meristic counts studied shows, in general, a possible discrimination between Tilapia zillii and the remainder species, especially by gill raker counts (Table 1). The distributions of the meristic characters considered also suggest that Lake Nasser and Ismailia populations of O.niloticus and S.galilaeus were isolated races. O.ismailiaensis became nearer to O.niloticus as regards the upper pored lateral line scale, anal soft fin ray, and caudal vertebral counts or nearer to S.galilaeus as regards total lower lateral line scale, caudal peduncle scale, dorsal fin spine, total dorsal fin ray, total gill raker and vertebral counts or occupied an intermediate position as regards the remainder characters.

The aforementioned interspecific discrimination became more obvious when the meristic characters studied were treated simultaneously by CVA \& PCA (Table 3 \& Fig. 2 ). O.niloticus populations were differentiated from S. galilaeus populations on CVI (59.84\%); O. ismailiaensis occupied an intermediate position between O.niloticus and S.galilaeus populations of Ismailia. Tilapia zillii was separated from the other tilapiine species studied, especially Lake Nasser populations. The discriminating power of CVI was given by vertebral counts of these species (TV versus PCV \& CV).

On CVII (34.84\%), Tilapia zillii exhibited complete separation from the remainder species. On such a vector, Lake Nasser and Ismailia populations of O.niloticus and S.galilaeus became differentiated (Fig.2A,B). The discriminating power of CVII was due to AFSR. CVIII (4.40\%) exhibited a low discriminating power for discrimination between species 


\section{I.A.A. MEKKEWY}

studied; such a power was due to DFS versus PCV \& TV (Table 3 ).

The application of sheared PCA, on the meristic characters studied in addition to SL as a measure of size, showed an intra- and interspecific pattern of discrimination other than that reflected by CVA. Tilapia zillii was separated from the remainder species by size on PCI $(49.80 \%)$; SL, the size measure, had the highest loading on that vector. Also, the size differences between Lake Nasser and Ismailia populations were evident on PCI. PCIII (10.69\%), the shape vector, was able to differentiate Tilapia zillii from other tilapiine species studied in torms of TGR count which has the highest loading (Fig. 2C, Table $3)$. The size components present in PCII $(25.90 \%)$ \& PCIII (10.69\%) were removed by sheared PCA (Fig.2D, Table 3). Before shearing, UULLS has the highest loading on PCII, whereas after shearing SL and TGR have the highest loadings. Accordingly, the discriminating power of the sheared PCII was almost similar to that of PCIII. This means that differentiation between Tilapia zillii and the remainder species and between Lake Nasser and Ismailia populations were due to shape components given by gill raker counts and standard length and not due to size component given on $\mathrm{PCI}$. The picture on sheared PCII was similar to that on PCIII before shearing. This means that no size components were found in PCIII (Fig.2 C\&D, Table 3). These results were confirmed by the absence of correlations between the meristic characters studied and fish size.

Populations analyses (Tables 4\&5) of O.niloticus and S.galilaeus were achieved in terms of sexual dimorphism and variability of samples within localities, between year classes and between different localities using the meristic counts considered. Each sample was differentiated according to sex into two subsamples.

Samples examined of O.niloticus of Lake Nasser and Ismailia exhibited no association between sex and meristic count distributions as regards LPLLS, LULLS, PCV, TV \&VF. However, as regards each of the remainder meristic counts, only one sample of 17 samples examined revealed sexual dimorphism. The accumulative information failed to give evidence of sexual dimorphism in the meristic characters studied. Since Lake Nasser and Ismailia samples revealed homogeneous results in different years, pooling of data was possible. Results of the pooled data revealed that the sex affected only UULLS (Lake Nasser), and TGR (Ismailia) counts.

Ismailia samples within year class 1991, as regards LPLLS, CV \& 
VF counts and Lake Nasser samples within 1989 , as regards TULLS, LPLLS, TLLLS, CPS, AFSR counts and within 1990, as regards VF counts were not homogeneous (Table 4).

Accordingly, it may be concluded that those samples of Ismailia in 1991 and Lake Nasser in 1989 \& 1990 represent different local populations of the same localities. Year-to-year variations were recorded in Lake Nasser samples as regards UULLS, AFSR, TGR, PCV, VF counts. Geographical variations in O.niloticus were recorded in different years in terms of all characters studied except UPLLS (in 1990), UULLS, LULLS counts (Table 4). Accordingly, Lake Nasser and Ismailia samples may be considered morphologically as isolated races.

Except one sample of 17 samples studied of S.galilaeus as regards TULLS, LPLLS, CPS, DFSR, AFSR, \& VF counts, all Lake Nasser and Ismailia samples exhibited no association between sex and different meristic counts considered; also the accumulative information exhibited insignificant sexual differences. Since Lake Nasser and Ismailia samples showed homogeneous results, pooling of data was possible. The pooled data revealed association between sex and LPLLS \&
LULLS counts of Lake Nasser and TLLLS counts of Ismailia.

As regards LPLLS, LULLS, TLLLS, DFSR (also in 1990) \& TV counts, only Lake Nasser samples of S. galilaeus within year class 1989 were heterogeneous (Table 5). The other samples were homogeneous in the remainder localities in different year classes. Accordingly, Lake Nasser samples in 1989 and 1990 represent different local populations of the same locality.

In meristic characters studied except TLLLS, AFSR \& TGR, year-to-year variations were not recorded in Lake Nasser populations of S.galilaeus (Table 5). Geographical variations of S.galilaeus were recorded by all meristic characters studied in different years (except by UULLS in 1989 and by LULLS, UULLS, CPS, DFS, DFSR \& PCV in 1990). Lake Nasser and Ismailia populations of S.galilaeus may be considered as isolated races.

The distributions of the meristic characters considered in the present investigation were compared with those of other authors working on the same species at different Egyptian regions (Tables 6-8). These tables and the previous ones refer to the fewer geographic variations in the majority of meristic characters of 


\section{I.A.A. MEKKEWY}

T.zillii in spite of the wide spectrum of environmental factors; gill rakers and upper pored lateral line scale counts exhibited obvious differences between the populations of that species. Little geographic differences were revealed by the means of the meristic characters (except those of gill rakers of Lake Nasser and Ismailia) of S. galilaeus, whereas the patterns of distributions of these characters referred to obvious geographic variations; Ismailia distributions included meristic counts that not found in other regions. In some meristic characters of O.niloticus, the patterns of distributions exhibited geographic variations, especially between Ismailia and upper Egypt populations. No clear association between the meristic counts of Tilapiine species studied and latitude can be detected in Egypt.

Figure 3 shows the overall pattern of intra- and inter-specific variations of the species studied in relation to Oreochromis aureus (BISHARA, 1973) from Lake Manzalah and Tilapia ismailiaensis (MEKKAWY, 1995b) from Ismailia canal. BISHARA (1973) recorded low gill raker counts in O.aureus (10 \& 12) in three specimens only; such low counts may be due to misidentification, therefore, they were not taken into consideration in the present comparisons. This figure reveals that T.zillii and T.ismailiaensis populations were clearly separated from those of the remainder species considered. Figure 3 also shows that species populations other than those of Tilapia species were divided into two subclusters: the first included Aswan and Ismailia populations of O.niloticus and the second grouped the remainder populations of O.niloticus and those of S.galilaeus, O.ismailiaensis and O.aureus.

Tables 9-12 exhibit that O.niloticus and S.galilaeus populations of Egypt were different from those of other African and Asian populations. In Egyptian populations of O.niloticus, a wide range of total vertebral counts (25-36) with new counts $(>33)$ were recorded to differentiate them from those of other regions (Table 9).

\section{DISCUSSION}

BEN-TUVIA $(1963 a, b)$ mentioned that the number of vertebrae of Sardinella aurita varies according to the water temperature, and since that fish spawns more than once during the season, there is a progressive decrease in the number of vertebrae of larvae spawned later, because the sea water becomes warmer as the summer progresses. PIVNICKA (1970) found that the means for almost all the meristic characters of burbot vary in association with 
temperature. BISHARA (1973) reported that the effect of temperature may explain the considerable wide range in the number of fin rays of Tilapia species which occurred in the following order: O.niloticus, O.aureus, S.galilaeus and Tilapia zillii since the fish have extended spawning period which amounts to about 9 months; some populations develop the early stages in the highest temperature of summer months, while others develop their early stages in comparatively lower temperature during spring and autumn. Similar conclusions were recorded in the present work for O.niloticus, S.galilaeus and T.zillii and no obvious trends towards the increase or decrease of the meristic characters considered with latitude were recorded. The absence of a definite trend toward increase or decrease with latitude may be due to eutrophication and pollution recorded in the Egyptian lakes; such conditions disturb temperature influences on the meristic characters in the sensitive periods of their production.

Year-to-year variations in meristic characters were reported by BEN-TUVIA (1963 a,b), RAFAIL (1970) in Sardinella aurita and Sardinella jussieu respectively and by MEKKAWY (1980) in Alestes nurse. RAFAIL (1970) interpreted the variability of ver- tebral counts from year to year to be due to year-to-year variations in the physical environment during spawning and early developmental stages. However, RAFAlL (1970) found that the vertebral counts of Sardinella sirm did not change from year to year in the same locality and he attributed this result to the relative insensitivity of vertebral number of that species to environmental factors during the critical early stages of development. In the present investigation, year-to-year variations were recorded in UPLLS, AFSR, TGR, PCV, VF of $O$. niloticus of Lake Nasser; no such variations were also recorded in TLLLS, AFSR, TGR of S.galilaeus. Moreover, comparing the present results with those of other authors revealed year-to-year variations.

Many investigators tried to assess the relative contributions of genetic or environmental influences on meristic variations. SCHMIDT (1919) concluded that while the numbers of fin rays or vertebrae are influenced by the environment, the possible range is determined genetically. HUBBS (1928) indicated that environmentally related clinal variation in meristic characters may reflect some degree of genetic differences. GORDON (1957) considered that many of the meristic traits that distinguish geographic 


\section{I.A.A. MEKKEWY}

races of fish are inherited, but that environmental conditions strongly influence the final expression. He thought that variability of such traits may be due to genetic drift. ITAZAWA (1959) in a study of Channa argus, found that though siblings differed in vertebral count according to the temperature at which they developed, genetic factors seemed to have more effect than environmental ones on the number of vertebrae present. BARLOW (1961) believed that regular changes in meristic counts such as those occur in geographic clines may reflect adaptive changes of genetic nature and he reviewed evidence that there is sometimes a selective advantage in a species having a given number of meristic elements in a given environmental situation. Thus, one may conclude that the meristic variations of geographic races or isolates are based partly upon environmental modifications, the extent of which is partially controlled by the genotype in an adaptive manner. McDOWALL (1972) stated that the assumption, that concordance between meristic variation and ecological-geographic gradients signifies that variation is environmentally induced, and is, therefore, of no significance in taxonomy, is unwarranted. He also mentioned that the assumption, that various isolates are all conspecific because their differences are largely related to environment, may sometimes be invalid. In the present investigation geographic variations in most of the meristic characters of species studied were recorded in different years by different analyses referring to interference of the genetic factors with environmental ones in their determination LIBOSVARSKY and BISHARA (1987) studied the morphometric characters of four Egyptian tilapiine species namely: Oreochromis niloticus, Oreochromis aureus, Sarotherodon galilaeus and Tilapia zillii. These authors discriminated in a multivariate shape sense between the first three species as one cluster and Tilapia zillii as another one. Oreochromis aureus occupied an intermediate position between Oreochromis niloticus and Sarotherodon galilaeus in terms of some shape patterns (raw traditional characters) and became in the side of Oreochromis niloticus in terms of some other ones (indices and residuals). Using multivariate analyses of traditional and truss morphometric size and shape patterns, MOHAMAD (1994) gave no obvious discrimination between four tilapiine species namely: Oreochromis niloticus, Oreochromis variabilis (identified later by the author as Oreochromis ismailiaensis), Sarotherodon galilaeus and Tilapia zillii. However, this author recorded geographic 
morphometric variations in $O$. niloticus and S.galilaeus on size and shape bases. The meristic distributions and patterns of variations, recorded in the present work in univariate and multivariate senses, revealed obvious intra- and inter-specific variations. T.zillii became completely differentiated from the remainder tilapiine species studied in terms of the majority of patterns of variations illustrated. Also, Lake Nasser populations of O.niloticus and S.galilaeus were clearly separated from those of Ismailia. Oreochromis ismailiaensis occupied an intermediate position between Ismailia populations in a multivariate sense, whereas in univariate sense it occupied an intermediate position according to some meristic characters, or became nearer to O.niloticus or to S.galilaeus according to another ones. MEKKAWY

(1995a) discriminated between that species and O.niloticus, S.galilaeus and O.aureus by electrophoretic analysis of their muscle proteins. $\mathrm{He}$ also pointed out that O.ismiliaensis was clearly differentiated from O.aureus in their external morphology including coloration. In the present work, O.ismailiaensis was grouped with the majority of S.galilaeus populations and some of O.niloticus populations, where-as O.aureus was clustered with Lake Manzalah population of S.galilaeus. Accordingly, one can conclude that inspite of the broad meristic sizefree variations of the tilapiine species studied, their usage in race and species identification is more preferable than that of the morphometric characteristics.

On the bases of the present results, and those of BISHARA (1973), LEVEQUE et al. (1992), and MEKKAWY (1995 a,b), the following key for the field identification of the Egyptian tilapiine species considered was built up.

1- Lower pharyngeal bone broader than long with anterior lamella not larger than dentigerous surface; 9-20 total gill-rakers on the first arch; 7-15 lower pored lateral line scales 2. -Lower pharyngeal bone longer than broad with anterior lamella longer than dentigerous surface; 18-34 total gill-rakers on the first arch; 10-24 lower pored lateral line scales

3.

2- Body elongated with straight ventral outline; straight head profile; relatively large eyes with extreme dorsolateral positions; dorsal fin originating just above the vertical of the posterior edge of the operculum; the width of the lower pharyngeal in its length is 1.66 ; 9 wide vertical bars on the flank with more obvious longitudinal lines; neither regular nor irregular yellow or white 


\section{I.A.A. MEKKEWY}

spots on the black caudal and dorsal fins. Tilapia ismailiaensis.

-Body oval with curved ventral outline; slightly curved head profile; relatively small eyes with lateral positions; dorsal fin originating behind the vertical of the posterior edge of the operculum; the width of the lower pharyngeal in its length is 1.33; no obvious vertical bars on the flank; no obvious longitudinal lines; regular or irregular yellow or white spots on the caudal and dorsal fins Tilapia zillii.

3- Scales between pectorals and pelvics much smaller than scales on the flanks; genital papilla of male and female well developed; 12-25 upper pored lateral line scales with mode of $23 ; 10-24$ lower pored lateral line scales with mode of 18 4.

-Scales between pectorals and pelvics not much smaller than scales on the flanks; genital papilla of male small and simple; 12-24 upper pored lateral line scales with mode of $20 ; 11-20$ lower pored lateral line scales with mode of 16 Sarotherodon galilaeus.
4- Caudal fin with regular vertical black size-related stripes (5-13) throughout its depth; 27-33 total dorsal fin rays and spines with mode of 30; 18-34 total gill-rakers on the first arch with mode of 29 Oreochromis niloticus.

-Caudal fin without regular vertical stripes; 26-30 total dorsal fin rays and spines with mode of $29 ; 20-30$ total gillrakers on the first arch with mode of 25 or 26 .................. 5 .

5- Red caudal fin with its pink dorsal side; head with curved profile; silvery iris ; pink red color along the dorsal fin edge; no obvious vertical bars on the body; 20-30 total gill-rakers with mode of $25(24.61 \pm 1.93)$.

.................... Oreochromis aureus.

-Dark red caudal fin with a black pyramid extending from its base to its margin; head with straight profile; black iris with a red circle around the pupil; black striations in a limited portion on the posteriormost soft dorsal fin rays; $7-8$ obvious vertical bars on the body; 20- 29 total gill-rakers with mode of $26(26.42 \pm 1.78)$. Oreochromis ismailiaensis.

\section{ACKNOWLEDGMENTS}

I would like to thank S. H. Mohamad, Assistant Lecturer, Faculty of Education, Suez Canal University, for her help in specimen collection.

\section{REFERENCES}

Barlow, G.W. (196l): Causes and significance of morphological variation in fishes. Syst. Zool., 10: 105-117. 
Beltagy, A.I. (1985): Sequences and consequences of pollution in Northern Egyptian lakes. 1. Lake Borollos. Bull. Inst. Oceanogr. \& Fish. ARE, 11:73-97.

Ben-Tuvia, A. (1963a): Influence of temperature on the vertebral number of Sardinella aurita from the eastern Mediterranean. Israel J. Zool. 12:59-66.

Ben-Tuvia, A. (1963b): Variation in vertebral number of young Sardinella aurita in relation to temperature during spawning season. Rapp. P.R, un. Commnint. Explor. Scient. Mer M,diterr. 17:313-8.

Bishara, N.F. (1973): Studies on the Biology of Tilapia Species in

Some Lakes in U.A.R. Ph.D. dissertation, Cairo University, Egypt. Blackith, R.E. and Reyment, R.A. (197l): Multivariate Morphometrics.

New York, Academic Press.

Davis, J.C. (1973): Statistics and Data Analysis in Geology, New York: Wiley.

Elewa, A.A. and Azazy, M. (1986): Comparative studies on microbiological and chemical characteristics of High Dam Lake within ten years. Bull. Nat. Inst. Oceanogr. \& Fish. ARE, 12: 315-322.

El-Otify, A.M.A.M. (1985): Studies on Phytoplankton of Aswan High Dam Lake. M.Sc. Thesis, Assiut University, Egypt.

Gordon, M. (1957): Physiological genetics of fishes. In: The Physiology of Fishes, Vol. 2 (Brown, M.E., ed), PP. 431-501. London: Academic Press.

Hubbs, C.L. (1928): A hypothesis on the origin of graded series of local races in fishes. Anat. Rec, 41:49.

Humphries, J.M.; Bookstein, F.L.; Chernoff, B.; Smith, G.R.; Elder, R.L. and Poss, S.G. (198l): Multivariate discrimination by shape in relation to size. Syst. Zool., 30:291-308.

Itazawa, $Y$. (1959): Influence of temperature on the number of vertebrae in fishes. Nature, London, 183: 1408-9.

Leveque, C.; Paugy, D. and Teugels, G.G. (1992): The Fresh and Brackish Water Fishes of West Africa. Vol.2, ORSTOM/MRAC: Paris/Tervuren.

Libosvarsky, J. and Bishara, N.F. (1987): Biometrics of Egyptian

Tilapiine Fishes; Methodology and Diagnosis. Acta Sc. Nat. Brno., 21(1): 1-46.

McAndrew, B.J. and Majumbar, K.C. (1984): Evolutionary relationships within three tilapiine genera (Pisces: Cichlidae). Zool. J. Linn. Soc., 80: 421-435. 


\section{I.A.A. MEKKEWY}

McDowall, R.M. (1972): The species problem in freshwater fishes and the taxonomy of diadromous and lacustrine populations of Galaxias maculatus (Jenyns). Journal of the Royal Society of New Zealand, 2(3):325-367.

Mekkawy, I.A.A. (1980): Taxonomic Studies of the Nile Fishes Family Characidae. M.Sc. Thesis, Assiut University, Egypt.

Mekkawy, I.A.A. (1987): Taxonomic Studies on Some Nile Mormyriform Fishes. Ph.D. dissertation, Assiut University, Egypt.

Mekkawy, I.A.A. (1995a): Description of Oreochromis ismailiaensis sp.n., and its hybrids with Oreochromis niloticus (Linnaeus, 1758) (Perciformes, Cichlidae) from Egypt. Bull. Fac. Sci., Assiut Univ., 24(1-E):1-27.

Mekkawy, I.A.A. (1995b): Description of Tilapia ismailiaensis sp.n. (Cichlidae) from Egypt. Bull. Fac. Sci., Assiut Univ., 24(1-E): 29-43

Mohamad, S.H. (1994): Biometric Studies on Fishes. M.Sc. Thesis, Assiut University, Egypt.

Moyle, P.B. and Cech, J.J. (1982): Fishes: An Introduction To Ichthyology. New Jersey: Prentice-Hall Inc. PP. 593.

Pivnicka, K. (1970): Morphological variation in the burbot, Lota lota, and recognition of the subspecies, a review. J. Fish. Res. Bd. Canada, 27: 1757-1765.

Rafail, S.Z. (1970): Studies of populations and exploitation status of Egyptian Red Sea abundant sardines. Bull. Inst. Ocean.\& Fish., U.A.R., 1: 129-148.

Saleh, M.S.M. (1980): Taxonomic Studies of the Nile Fishes: Family Cichlidae. M.Sc. Thesis, Assiut University, Egypt.

Samaan, A.A. and Abdel-Moneim (1986): Some physical features of the polluted basin and fish farm in Lake Mariut, Egypt. Bull. Inst. Oceanogr. \& Fish., ARE, 12: 149-163.

Schmidt, J. (1919): Racial investigations. III. Experiments with Lebistes reticulatus (Peters) Regan. C.r. Trav. Lab. Carlsberg, 14(5): 1-7.

Trewavas, E. (1982): Taxonomy and speciation. In: The Biology and Cultures of Tilapias. (Pullin \& Mc Connell, Eds.) Manila.

Trewavas, E. (1983): Tilapiine Fishes of the Genera Sarotherodon, Oreochromis and Danakilia. London: British Museum (Natural History).

Witte, F. (1984): Consistency and functional significance of morphological differences between wild-caught and domestic Haplochromis aquamipinnis (Pisces, Cichlidae). Neth. J. Zool., 34(4): 596-612. 


\section{I.A.A. MEKKEWY}

Table 1: Cont.

\begin{tabular}{|c|c|c|c|c|c|c|c|c|c|c|c|c|c|c|c|c|c|c|}
\hline \multirow[t]{2}{*}{ Counts } & \multicolumn{3}{|c|}{$\begin{array}{c}0 . \\
\text { Ismailia }\end{array}$} & \multicolumn{3}{|c|}{$\frac{\text { niloticus }}{\text { Aswan }}$} & \multicolumn{5}{|c|}{ 0. ismailiaensis } & \multicolumn{3}{|c|}{$\begin{array}{l}\text { S. galilaeus } \\
\text { I11a Aswan }\end{array}$} & \multicolumn{4}{|c|}{$\begin{array}{l}\text { T. zillii } \\
\text { Ismailia } \\
\end{array}$} \\
\hline & $M$ & 1. $F$. & C. & M. & F. & C. & M. & F. & C. & M. & F. & C. & M. & F. & C. & M. & F. C & C. \\
\hline \multicolumn{19}{|c|}{ Lower unpored lateral line scale counts } \\
\hline 9 & 2 & - & 2 & & & & & & & & & & & & & & & \\
\hline 10 & 1 & - & 1 & 1 & 1 & 2 & & & & & & & & & & & & \\
\hline 11 & & & & 2 & 2 & 4 & 2 & 1 & 3 & 2 & - & & & & & & & \\
\hline 12 & 2 & 1 & 3 & 17 & 5 & 22 & 6 & 51 & 11 & 3 & 2 & 5 & 2 & 2 & 4 & & & \\
\hline 13 & 8 & 1 & 9 & 31 & 11 & 42 & 10 & 71 & 17 & 7 & 6 & 13 & 17 & 5 & 22 & 1 & - & 1 \\
\hline 14 & 9 & 6 & 15 & 48 & 27 & 75 & 15 & 82 & 23 & 7 & 5 & 12 & 62 & 24 & 86 & 5 & 4 & 9 \\
\hline 15 & 11 & 14 & 25 & 55 & 28 & 83 & 9 & 71 & 16 & 14 & 13 & 27 & 72 & 71 & 143 & 10 & 21 & 12 \\
\hline 16 & 7 & 4 & 11 & 28 & 20 & 48 & 8 & 61 & 14 & 8 & 10 & 18 & 48 & 23 & 71 & 9 & 31 & 12 \\
\hline 17 & 2 & 2 & 4 & 10 & 13 & 23 & 2 & - & 2 & 5 & 7 & 12 & 5 & 6 & 11 & 2 & 1 & \\
\hline 18 & 1 & 2 & 3 & 1 & 2 & 3 & - & 1 & 1 & 1 & - & 1 & 2 & - & 2 & 3 & 1 & \\
\hline 19 & 1 & 1 & 2 & 3 & - & 3 & & & & & & & & & & 1 & - & \\
\hline 20 & & & & 1 & - & 1 & & & & - & 1 & 1 & & & & 1 & - & \\
\hline & & & & & otal & 1 low & & ater & ral & line & scal & & count & & & & & \\
\hline 25 & & & & & & & & & & & & & & & & - & 1 & 1 \\
\hline 26 & - & 1 & 1 & & & & 1 & 1 & 2 & 1 & 3 & 4 & & & & & & \\
\hline 27 & & & & & & & 7 & 1 & 9 & 2 & - & 2 & & & & & & \\
\hline 28 & 2 & 1 & 3 & & & & 20 & 72 & 27 & 2 & 5 & 7 & 3 & 3 & 6 & 2 & - & 2 \\
\hline 29 & 1 & 2 & 3 & 3 & 1 & 4. & 11 & 6 & 17 & 4 & 12 & 16 & 20 & 13 & 33 & 7 & 6 & 13 \\
\hline 30 & 4 & 5 & 9 & 5 & 1 & 6 & 2 & - & 2 & 20 & 9 & 29 & 61 & 44 & 105 & 19 & 7 & 26 \\
\hline 31 & 13 & 8 & 21 & 27 & 11 & 38 & & & & 11 & 8 & 19 & 97 & 61 & 158 & 17 & 18 & 35 \\
\hline 32 & 21 & 9 & 30 & 61 & 31 & 92 & & & & 10 & 13 & 23 & 25 & 8 & 33 & 7 & 7 & 14 \\
\hline 33 & 9 & 7 & 16 & 83 & 47 & 130 & & & & 1 & - & 1 & 5 & 3 & 8 & 5 & - & 5 \\
\hline 34 & 1 & 2 & 3 & 19 & 19 & 38 & & & & & & & 1 & - & & - & 1 & 1 \\
\hline 35 & & & & 2 & 1 & 3 & & & & & & & & & & & & \\
\hline 36 & & & & - & 1 & 1 & & & & & & & & & & & & \\
\hline
\end{tabular}


Table 1: Cont.

\begin{tabular}{|c|c|c|c|c|c|c|c|c|c|c|c|c|c|c|c|c|c|c|}
\hline \multirow[t]{2}{*}{ Counts } & \multicolumn{3}{|c|}{$\frac{0 .}{\text { Ismailia }}$} & \multicolumn{3}{|c|}{$\frac{\text { niloticus }}{\text { Aswan }}$} & \multicolumn{4}{|c|}{ 0. ismailiaensis } & $\frac{i s}{\operatorname{smaj}}$ & \multicolumn{3}{|c|}{ S. galilaeus } & & \multicolumn{3}{|c|}{$\frac{\text { T. zillil }}{\text { Ismailia }}$} \\
\hline & M. & F. & C. & M. & F. & C. & M. 1 & F. & C. & M. & $\mathrm{F}$. & C. & M. & F. & C. & M. & & c. \\
\hline & & & & & & auda] & 1 ped & unc & cle & scale & $\mathrm{co}$ & unt & & & & & & \\
\hline 15 & - & 1 & 1 & & & & - & 1 & 1 & 1 & 2 & 3 & 1 & - & 1 & 6 & 3 & 9 \\
\hline 16 & 1 & 1 & 2 & 1 & - & 1 & 7 & 61 & 13 & 17 & 22 & 29 & 47 & 40 & 87 & 32 & 9 & 41 \\
\hline 17 & 5 & 1 & 6 & 4 & - & 4 & 2112 & 23 & 33 & 9 & 9 & 18 & 86 & 50 & 136 & 3 & 2 & 5 \\
\hline 18 & 8 & 7 & 15 & 24 & 184 & 42 & 2613 & 33 & 39 & 12 & 8 & 30 & 65 & 32 & 97 & & & \\
\hline 19 & 22 & 13 & 35 & 70 & 401 & 110 & 5 & 51 & 10 & 9 & 4 & 13 & 13 & 12 & 25 & & & \\
\hline 20 & 10 & 6 & 26 & $66=$ & 329 & 98 & & 1 & 1 & 2 & 3 & 5 & 4 & - & 4 & & & \\
\hline 21 & 2 & 2 & 4 & 462 & 247 & 70 & & & & & & & & & & & & \\
\hline 22 & 3 & 2 & 5 & 2 & 5 & 7 & & & & & & & & & & & & \\
\hline 23 & & & & 1 & - & $1 \cdot \mathrm{I}$ & Dorsa & $1 \mathrm{f}$ & fin & spine & & & & & & & & \\
\hline XIV & & & & & & & & & & 1 & 1 & 2 & & & & 2 & 2 & 4 \\
\hline XV & 1 & 4 & 5 & & & & 9 & 9 & 18 & 10 & 11 & 21 & 2 & 1 & 5 & 35 & 11 & 46 \\
\hline XVI & 8 & 3 & 11 & 8 & 3 & 11 & $452^{\prime}$ & 7 & 72 & 37 & 31 & 68 & 182 & 116 & 298 & 5 & 3 & 8 \\
\hline XVII & 34 & 24 & 58 & 144 & 802 & 230 & 5 & 4 & 9 & 2 & 7 & 9 & 32 & 19 & 53 & & & \\
\hline XVIII & 8 & 3 & 11 & 603 & 36 & 99 & & & & & & & & & & & & \\
\hline & & & & & & Soft & ray & & of $d$ & orsal & $1 \mathrm{fi}$ & & & & & & & \\
\hline 9 & & & & & & & & & & & & & & 1 & 1 & & & \\
\hline 11 & - & 1 & 1 & & & & -2 & 2 & 2 & 1 & 1 & 2 & & & & 11 & 6 & 17 \\
\hline 12 & 19 & 12 & 33 & 17 & 10 & 27 & 18 & 4 & 22 & 16 & 16 & 32 & 12 & 12 & 25 & 26 & 66 & 32 \\
\hline 13 & 27 & 16 & 43 & 123 & 55 & 181 & 38 & 32 & 70 & 29 & 28 & 57 & 107 & 65 & 172 & & 43 & 7 \\
\hline 14 & 2 & 6 & 8 & 73 & 47 & 125 & 3 & 2 & 5 & 5 & 4 & 9 & 95 & 57 & 154 & & & \\
\hline 15 & & & & 2 & 5 & 7 & & & & & & & 1 & - & 1 & & & \\
\hline
\end{tabular}


Table 1: Cont.

\begin{tabular}{|c|c|c|c|c|c|c|c|c|c|c|c|c|c|c|c|c|}
\hline \multirow[t]{2}{*}{ Counts } & \multicolumn{3}{|c|}{$\frac{0 .}{\text { Ismailia }}$} & \multicolumn{3}{|c|}{$\begin{array}{c}\text { niloticus } \\
\text { Aswan }\end{array}$} & \multicolumn{4}{|c|}{0. ismailiaensis } & $\frac{\text { S. }}{11 \mathrm{a}}$ & \multicolumn{2}{|c|}{$\frac{\text { galilaeu }}{\text { Aswan }}$} & \multicolumn{3}{|c|}{$\frac{T \cdot z i l l i i}{\text { Ismailla }}$} \\
\hline & M. & 1. $F$. & C. & M. & F. & C. & M. $\mathrm{I}$ & $\mathrm{F}$. & C. & M. F. & C. & M. 1 & F. & C. & M. F. & C. \\
\hline \multicolumn{17}{|c|}{ Dorsal fin spines and rays } \\
\hline 24 & & & & & & . & & & & & & & & 1 & & \\
\hline 26 & & & & & & & & & 1 & & 2 & & & & & 15 \\
\hline 27 & & & 4 & & & & & & 2 & & 7 & & & & & 28 \\
\hline 28 & & & 4 & & & 1 & & & 24 & & 29 & & & 11 & & 9 \\
\hline 29 & & & 29 & & & 11 & & & 64 & & 50 & & & 157 & & 1 \\
\hline 30 & & & 35 & & & 142 & & & 5 & & 9 & & & 177 & & \\
\hline 31 & & & 12 & & & 161 & & & & & & & & 7 & & \\
\hline 32 & & & & & & 23 & & & & & & & & & & \\
\hline 33 & & & & & & 2 & & & & & & & & & & \\
\hline \multicolumn{17}{|c|}{ Soft rays of anal fin } \\
\hline 7 & & & & - & 1 & 1 & & & & & & & & & & \\
\hline 8 & 1 & 1 & 2 & & & & $1-$ & -1 & 1 & & & & & & 132 & 15 \\
\hline 9 & 19 & 12 & 31 & 26 & 9 & 37 & 115 & 5 & 16 & 66 & 12 & & & & 2211 & 33 \\
\hline 10 & 27 & 18 & 45 & 142 & 78 & 234 & 393 & 327 & 71 & 2531 & 56 & 10 & 10 & 20 & 61 & 7 \\
\hline 11 & 3 & 4 & 7 & 33 & 30 & 63 & 8 & 31 & 11 & 1911 & 30 & 1397 & 77 & 218 & & \\
\hline 12 & & & & 1 & 1 & 2 & & & & 12 & 3 & 70 & 49 & 120 & & \\
\hline 13 & & & & & & & & & & & & & 1 & 1 & & \\
\hline
\end{tabular}


Table 1: Cont.

\begin{tabular}{|c|c|c|c|c|c|c|c|c|c|c|c|c|c|c|c|c|c|c|}
\hline \multirow[t]{2}{*}{ Counts } & \multicolumn{3}{|c|}{$\begin{array}{c}0 . \\
\text { Ismailia }\end{array}$} & \multicolumn{3}{|c|}{$\begin{array}{c}\text { niloticus } \\
\text { Aswan }\end{array}$} & \multicolumn{5}{|c|}{$\frac{0 . \text { ismailiaensis }}{\text { Ismailia }} \frac{\text { Isma }}{\text { Istion }}$} & \multicolumn{3}{|c|}{$\begin{array}{l}\text { S. galilaeus } \\
\text { ilia Aswan }\end{array}$} & \multicolumn{4}{|c|}{$\begin{array}{l}\text { T. zillii } \\
\text { Ismailia }\end{array}$} \\
\hline & M & 1. $\mathrm{F}$ & F. C. & M. & F. & C. & M & . F. & C. & M. & F. & C. & M. & 1. $\mathrm{F}$. & C. & M. & $\mathbf{F}$. & C. \\
\hline & & & & & & & & otal & gill & rak & kers & & & & & & & \\
\hline 10 & & & & & & & & & & & & & & & & 1 & - & 1 \\
\hline 11 & & & & & & & & & & & & & & & & 2 & 1 & 3 \\
\hline 12 & & & & & & & & & & & & & & & & 13 & 5 & 18 \\
\hline 13 & & & & & & & & & & & & & & & & 14 & 6 & 20 \\
\hline 14 & & & & & & & & & & & & & & & & 9 & 2 & 11 \\
\hline 15 & & & & & & & & & & & & & & & & 1 & - & 1 \\
\hline 18 & & & & - & 1 & 1 & & & & & & & & & & & & \\
\hline 19 & & & & & & & & & & 1 & - & 1 & & & & & & \\
\hline 20 & & & & & & & 1 & - & 1 & & & & & & & & & \\
\hline 21 & & & & & & & & & & - & 1 & 1 & & & & & & \\
\hline 22 & & & & & & & - & 1 & 1 & - & 2 & 2 & & & & & & \\
\hline 23 & 1 & - & 1 & & & & 1 & - & 1 & 1 & 4 & 5 & & & & & & \\
\hline 24 & 1 & - & 1 & & & & 6 & 3 & 9 & 8 & 61 & 14 & 2 & 1 & 3 & & & \\
\hline 25 & 2 & 4 & 6 & 2 & - & 2 & 7 & 9 & 16 & 9 & 41 & 13 & 8 & 4 & 12 & & & \\
\hline 26 & 5 & 2 & 7 & 2 & - & 3 & 11 & 7 & 18 & 12 & 82 & 20 & 34 & 11 & 45 & & & \\
\hline 27 & 7 & 3 & 10 & 9 & 4 & 13 & 9 & 8 & 17 & 6 & 61 & 12 & 50 & 31 & 82 & & & \\
\hline 28 & 9 & 2 & 11 & 34 & 17 & 52 & 12 & 4 & 16 & 8 & 41 & 12 & 59 & 46 & 106 & & & \\
\hline 29 & 11 & 5 & 16 & 54 & 36 & 90 & 4 & 8 & 12 & 3 & 4 & 7 & 40 & 22 & 62 & & & \\
\hline 30 & 2 & 7 & 9 & 53 & 30 & 86 & & & & 1 & 3 & 4 & 21 & 12 & 34 & & & \\
\hline 31 & 5 & 8 & 13 & 32 & 20 & 52 & & & & - & 1 & 1 & 2 & 2 & 4 & & & \\
\hline 32 & 5 & 2 & 7 & 16 & 7 & 24 & & & & & & & 2 & 1 & 3 & & & \\
\hline 33 & - & 1 & 1 & 11 & 3 & 14 & & & & & & & & & & & & \\
\hline 34 & & & & 1 & - & 1 & & & & & & & & & & & & \\
\hline
\end{tabular}


I.A.A. MEKKEWY

Table 1: Cont.

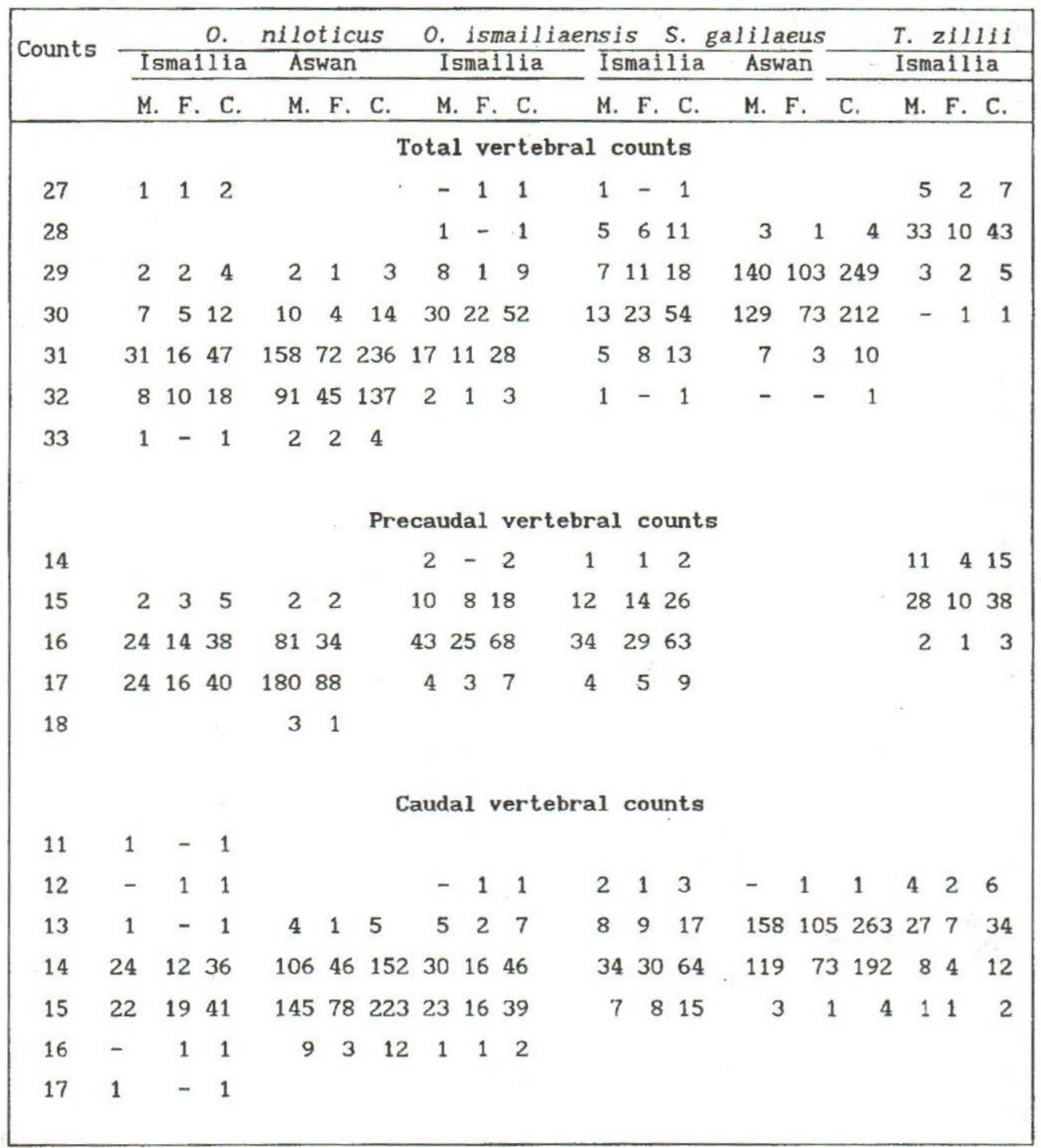


Cont.

\begin{tabular}{|c|c|c|c|c|c|c|c|}
\hline & eochro & s nilot & & & otherod & galil & \\
\hline & & & & & & & \\
\hline Males & Females & Males & Females & Males & Females & Males & Females \\
\hline & & . & 1 & & & $\begin{array}{l}1 \\
1\end{array}$ & 1 \\
\hline & & & & 3 & & 3 & 5 \\
\hline 1 & & 1 & 1 & 4 & 4 & 5 & 7 \\
\hline 6 & 6 & $\begin{array}{l}1 \\
1\end{array}$ & 1 & & & 2 & 2 \\
\hline & & & & & 1 & 1 & 1 \\
\hline 1 & 1 & 1 & & 138 & 97 & 2 & 4 \\
\hline 7 & 2 & 6 & 4 & 116 & 56 & 25 & 19 \\
\hline $\begin{array}{c}55 \\
9\end{array}$ & 24 & 15 & 9 & 3 & 1 & 4 & 5 \\
\hline$y$ & & 1 & & & & & \\
\hline 2 & & & & 13 & 6 & 2 & 1 \\
\hline 96 & 42 & 16 & 7 & 4 & 2 & 1 & 1 \\
\hline 82 & & & & & & 1 & \\
\hline & 1 & & & & & & \\
\hline $\begin{array}{l}1 \\
2\end{array}$ & 1 & & & & & & \\
\hline
\end{tabular}

: Results of intra- and inter-specific differences of tilapiine species studied by Chi-square $=$ insignificant; ${ }^{*}=$ significant at $0.05 ; * *=$ significant at 0.01 ).

\begin{tabular}{|c|c|c|c|c|c|c|c|c|}
\hline \multicolumn{6}{|c|}{ Sex differences } & \multicolumn{2}{|c|}{ Locality differences } & \multirow{3}{*}{$\begin{array}{l}\text { Interspecific } \\
\text { differences }\end{array}$} \\
\hline \multicolumn{2}{|c|}{ O. niloticus } & \multicolumn{2}{|c|}{ S. galilaeus } & \multirow{3}{*}{$\begin{array}{c}\text { O.ismailiaensis } \\
\text { Ismailia }\end{array}$} & \multirow{3}{*}{$\begin{array}{l}\text { T. zillii } \\
\text { Ismailia }\end{array}$} & & & \\
\hline & Ismailia & Aswan & & & & & S. & \\
\hline . & - & - & & & & niloticus & galilaeus & \\
\hline & - & & & - & - & * & *** & $* *$ \\
\hline & & $=$ & - & $=$ & - & - & - & - \\
\hline$=$ & $=$ & - & - & - & - & - & - & - \\
\hline- & - & * & - & - & $=$ & - & - & - \\
\hline- & - & $* *$ & - & $=$ & - & - & - & - \\
\hline$=$ & - & - & * & - & - & - & - & $=$ \\
\hline- & - & - & - & - & - & ** & ** & ** \\
\hline- & - & - & - & * & - & ** & ** & ** \\
\hline- & - & - & - & - & - & ** & ** & ** \\
\hline- & - & - & - & - & - & $* *$ & ** & ** \\
\hline- & * & - & - & - & - & ** & ** & ** \\
\hline- & - & - & - & - & - & - & - & - \\
\hline- & - & - & - & - & - & $=$ & - & - \\
\hline- & - & - & - & - & - & ** & ** & ** \\
\hline- & - & - & $=$ & - & - & - & - & - \\
\hline
\end{tabular}




\section{I.A.A. MEKKEWY}

Table 3 :Canonical variates and principal components derived from CVA and PCA of certain meristic characters of tilapiine populations considered as combined sexes; $\mathrm{SL}$ was included in PCA (coefficient $x$ 1000).

\begin{tabular}{|l|cccccccc|}
\hline \multirow{2}{*}{$\begin{array}{c}\text { Meristic } \\
\text { characters }\end{array}$} & \multicolumn{4}{|c}{ Canonical variates } & \multicolumn{5}{c|}{ Principal components } \\
\cline { 2 - 9 } & CVI & CVII & CVIII & PCI & PCII & $\begin{array}{l}\text { Sheared } \\
\text { PCII }\end{array}$ & PCIII & $\begin{array}{l}\text { Sheared } \\
\text { PCIII }\end{array}$ \\
\hline SL & - & - & - & 858 & 043 & 046 & -473 & -466 \\
UPLLS & 044 & -178 & 109 & 099 & -199 & 004 & 176 & 176 \\
UULLS & 007 & -160 & 122 & -058 & 962 & 001 & 026 & 026 \\
LPLLS & 025 & 058 & -046 & 196 & -036 & 010 & 443 & 442 \\
LULLS & 014 & 045 & -100 & -019 & 025 & -001 & -279 & -278 \\
CPS & 083 & -098 & -099 & 129 & -060 & 007 & 142 & 142 \\
DFS & 162 & 346 & -609 & 082 & -022 & 004 & 079 & 079 \\
DFSR & 039 & 333 & -304 & 085 & 033 & 005 & 017 & 017 \\
AFSR & -166 & 701 & -044 & 085 & 103 & 005 & -035 & -034 \\
TGR & 002 & 219 & 093 & 404 & 116 & 022 & 638 & 637 \\
PCV & -538 & 245 & 445 & 069 & -005 & 004 & 075 & 075 \\
CV & -494 & -028 & 492 & 038 & -038 & 002 & 137 & 136 \\
TV & 633 & -311 & 194 & 055 & -020 & 002 & 104 & 103 \\
Variance & 59.84 & 34.84 & 4.40 & 49.8 & 25.9 & & 10.69 & \\
\hline
\end{tabular}




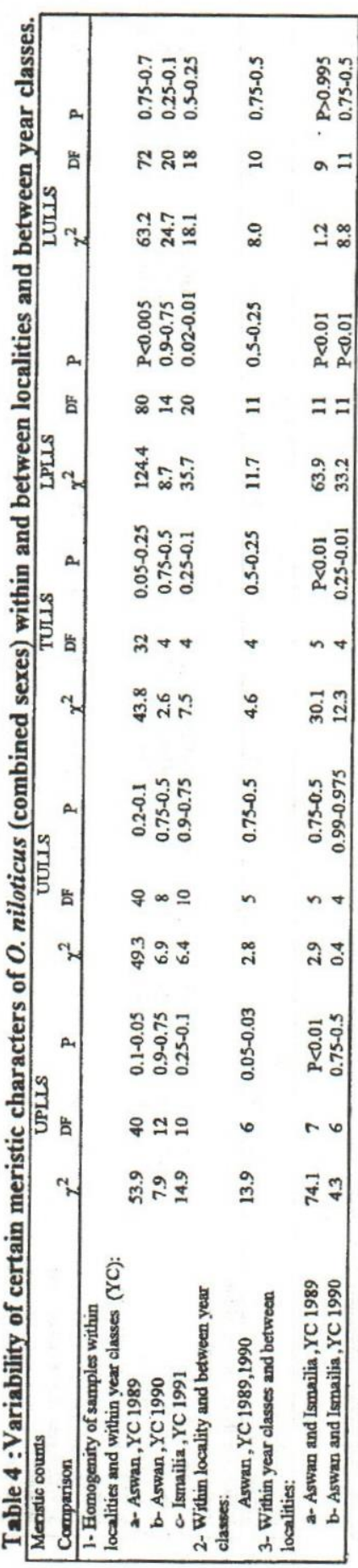

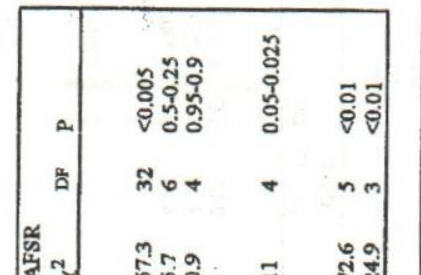

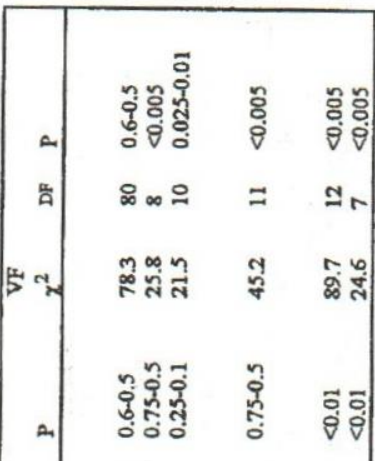

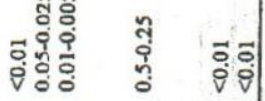

苔 苏

局

藏

ret

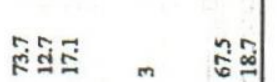

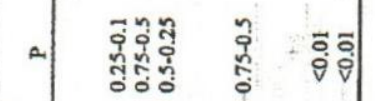

电

猎

$2+$

4.

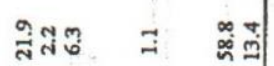

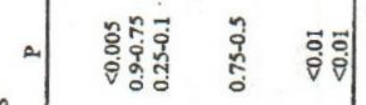

离

ช

ชู

$n_{\infty}^{\infty} \rightarrow n$

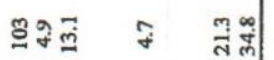

ํํㅇ우웅 웅 흥혀

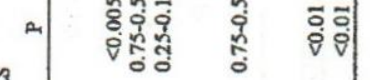

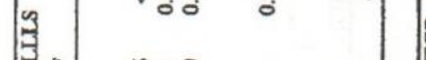

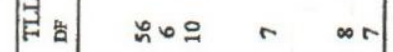

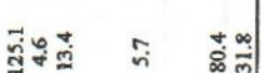

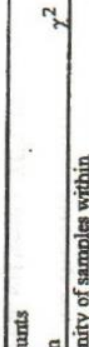




\section{I.A.A. MEKKEWY}

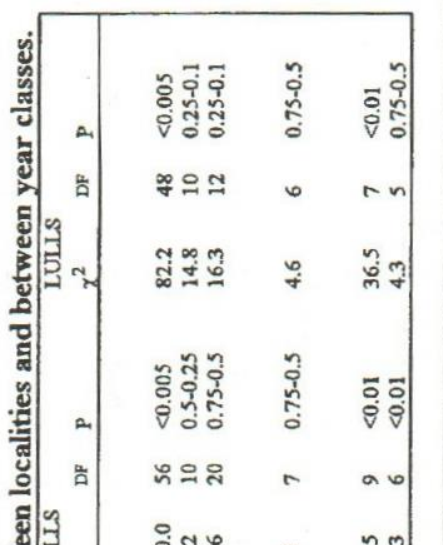

舸以

흘



है

ॠ

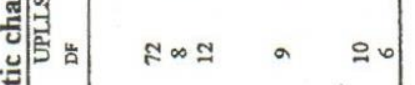

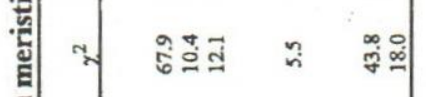

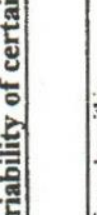

\begin{tabular}{|c|c|c|c|}
\hline Q.1 & 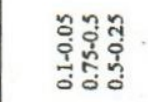 & $\begin{array}{l}\text { ¿̋ } \\
\dot{0} \\
\dot{0}\end{array}$ & ōं \\
\hline 范 & $\stackrel{0}{\circ}$ & m & $\mathrm{mem}$ \\
\hline 资 & 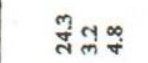 & 임 & $\underset{7}{*}$ \\
\hline A. & 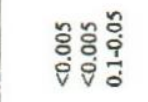 & $\begin{array}{l}n \\
\vdots \\
0 \\
0\end{array}$ & cั \\
\hline 荢 & స్లెం & $\nabla$ & $\mathrm{mm}$ \\
\hline 発 & 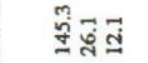 & aे & త్లై \\
\hline A. & 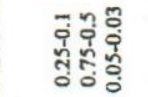 & 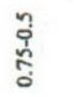 & 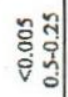 \\
\hline 㟔 & $\mathscr{+}+0$ & $\mathrm{~N}$ & $N$ \\
\hline శ. & กั่ & 9 & $\frac{7}{\infty}=$ \\
\hline$\infty$ & 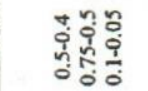 & के & है \\
\hline 告 & g 09 & $n$ & $n+$ \\
\hline N & 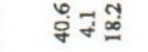 & 2 & लू \\
\hline an & 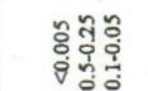 & 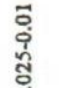 & ฮั่े \\
\hline 台 & $\underset{+}{\infty} 60$ & 6 & $\infty+$ \\
\hline ل & 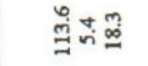 & घ̆ & ธิ่ \\
\hline 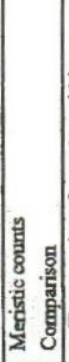 & 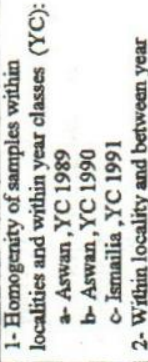 & 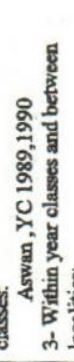 & 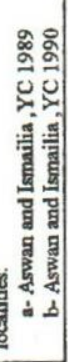 \\
\hline
\end{tabular}

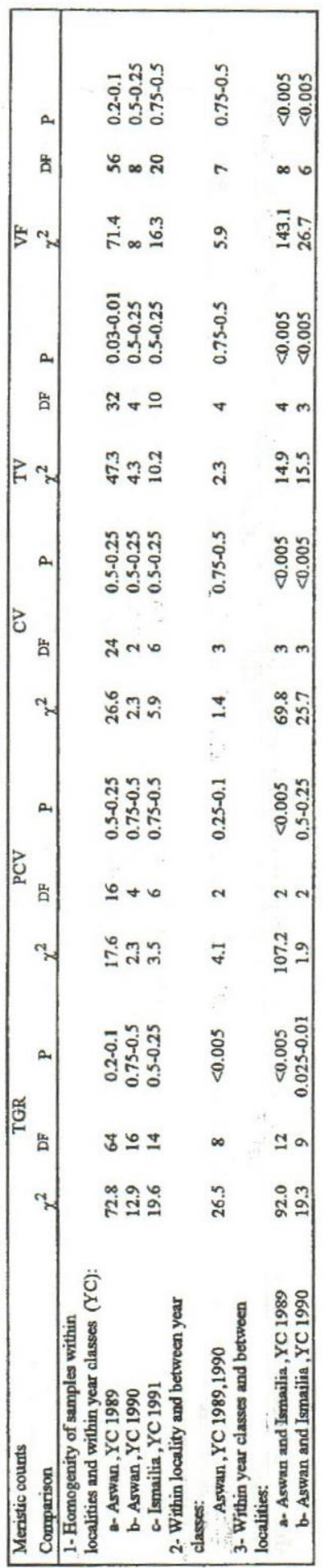


Table 6 : Comparisons of some meristic characters of o. niloticus in different Egyptian waters.

\begin{tabular}{llll}
\hline \multirow{2}{*}{ Counts } & Bishara (1973) & Saleh (1980) & Present work \\
\cline { 2 - 4 } & Lake Manzalah & $\begin{array}{l}\text { The Nile at } \\
\text { Sohag Aswan }\end{array}$ & Aswan Ismailia \\
\hline
\end{tabular}

12

17

18

19

20

21

22

23

24

25

26

27

7

8

9

10

11

$\frac{12}{\mathrm{X}}+$

25

26

27

28

29

30

31

32

33

34

35

$\frac{36}{\mathrm{X}}+\mathrm{SD}$

14

15

16

17

18

$\overline{\mathrm{X}}+\mathrm{SD}$

11

12

13

14

15

16

$\frac{17}{\mathrm{X}}+\mathrm{SD}$
Upper pored lateral line scale counts

$$
2
$$$$
21
$$$$
\text { 1 } 2
$$$$
7
$$

$$
16
$$

22

28

4

1

21. $91 \overline{+1} .5622 .90 \overline{+1} .84$

22. $89+0.91$

22. $12+1.49$

Soft anal $f$ in rays w*⿻丷木 $^{*}$

$\begin{array}{rr}2 & 1 \\ 2 & 4 \\ 30 & 7 \\ 118 & 34 \\ 146 & 30 \\ 38 & 4\end{array}$

3

$\begin{array}{rrrr}29 & 7 & 1 & \\ 74 & 96 & 37 & 31 \\ 16 & 11 & 234 & 45 \\ 1 & 1 & 63 & 7 \\ & & 2 & -\end{array}$

$9.54 \div 0.50 \quad 8.91 \overline{+0} 0.64 \quad 9.05 \div 0.44 \quad 10.08 \overline{+0} .589 .67 \overline{+0} 0.66$ Total vertebral counts

1

1

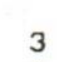

1

9

13

5

2

3

1

2

$31.02 \div 2.27 \quad 31.89 \mp 0.7932 .46 \mp 0.6731 .32 \mp 0.5930 .91 \mp 0.98$ Precaudal vertebral counts

1

$\begin{array}{rrrl} & & 4 & 5 \\ 11 & & 115 & 38 \\ 58 & 29 & 268 & 40 \\ 37 & 45 & 4 & \end{array}$

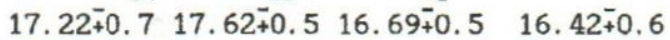
Caudal vertebral counts

$\begin{array}{rrrr} & & & 1 \\ 35 & 1 & 5 & 1 \\ 72 & 16 & 152 & 1 \\ & 50 & 223 & 36 \\ & 7 & 12 & 41 \\ & & & 1\end{array}$

$\begin{array}{llll}14.67 \div 0.5 & 14.85 \div 0.6 & 14.62 \div 0.57 & 14.49 \div 0.77\end{array}$ 


\section{I.A.A. MEKKEWY}

Table 6 . Cont.

\begin{tabular}{llll}
\hline \multirow{2}{*}{ Counts } & Bishara (1973) & Saleh (1980) & Present work \\
\cline { 2 - 4 } & Lake Manzalah & $\begin{array}{l}\text { The Nile at } \\
\text { Sohag Aswan }\end{array}$ & Aswan Ismailia \\
\hline
\end{tabular}

11

12

13

14

$\frac{15}{\mathrm{X}}$

SD

XV

XVI

XVII

XVIII

XIX

$\overline{\mathrm{X}}$

SD

25

26

27

28

29

30

31

32

33

SD

18

20

21

22

23

24

25

26

27

28

29

30

31

32

33

$\frac{34}{\mathrm{X}}$

SD

5

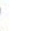

8

Soft rays of dorsal fin

$\begin{array}{rrrr}29 & 4 & - & 1 \\ 56 & 52 & 27 & 33 \\ 40 & 61 & 181 & 42 \\ & & 125 & 8\end{array}$

12. 49

0.65

$12.09 \quad 12.49$

$\begin{array}{ll}0.74 & 0.57\end{array}$

13. 33

12. 68

Dorsal fin spines

1

26

72

7

$\begin{array}{rr}8 & 2 \\ 96 & 78 \\ 21 & 35\end{array}$

0.65

0.66

16.80

0.56

$17.10 \quad 17.32$

$0.74 \quad 0.54$

17.26

0.51

16. 88

Dorsal fin rays and spines
5

11

58

11

$99 \quad 11$

1
3
2
8
68
66
5
1
8
1
88
69

$\begin{array}{rr}53 \\ 0 & 39 \\ 1 & 3\end{array}$

3
8
53
39
3

$\begin{array}{rr}1 & \\ 21 & 1 \\ 60 & 32 \\ 39 & 73 \\ 4 & 11\end{array}$

$\begin{array}{rr} & 4 \\ 1 & 4 \\ 11 & 29 \\ 142 & 35 \\ 161 & 12 \\ 23 & \\ 2 & \end{array}$

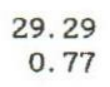

29. $19 \quad 29.80$

$0.78 \quad 0.61$

30.59

0.70

29. 56

Total gill rakers

1

$\begin{array}{rrr}7 & 3 & 1 \\ 11 & 6 & - \\ 7 & 4 & 1 \\ 5 & 4 & - \\ 5 & 11 & 2 \\ 14 & 18 & 3 \\ 4 & 14 & 9 \\ 14 & 11 & 16 \\ 9 & 21 & 25 \\ 7 & 17 & 22 \\ 14 & 12 & 23 \\ 1 & 5 & 8 \\ & 3 & 2 \\ & & 1\end{array}$

26. 49

3.29

26.61

28. 37

$2.01 \quad 1.64$

2. 86

28. 67

2. 23 
INTRA-AND INTER-SPECIFIC VARIATIONS, MERISTIC CHARACTERISTICS, TILAPINE SPECIES OF EGIPT

Table 7 : Cumpal 1 sons of some meristic cliaraclers of S. galilaeus in different Egyptian waters

\begin{tabular}{llll}
\hline \multirow{2}{*}{ Counts } & Bishara (1973) & Saleh (1980) & Present work \\
\cline { 2 - 4 } & Lake Manzalah & $\begin{array}{c}\text { The Nile at } \\
\text { Aswan }\end{array}$ & Aswan Ismailia \\
& &
\end{tabular}

12

Upper pored lateral line scale counts

$\begin{array}{rr} & 3 \\ 1 & - \\ 3 & 1 \\ 2 & 1 \\ 8 & 6 \\ 50 & 13 \\ 164 & 29 \\ 99 & 22 \\ 18 & 12 \\ 1 & 3 \\ 1 & 5 \\ & - \\ 20.15 & 20.2 \\ 1.02 & 2.13\end{array}$

Soft rays of dorsal fin

9
10
11
12
13
14
15
$\frac{\mathrm{x}}{4}$

$\begin{array}{rr} & 12.38 \\ \text { SD } & 0.79\end{array}$

XIV

XV 18

XVI $\quad 58$

XVII 9

$\begin{array}{ll}\mathrm{X} & 15.81\end{array}$

SD

0.67

11
38
3
12.85
0.50

Dorsal fin spines

24

Dorsal $f$ in spines and rays

$\begin{array}{cc} & 2 \\ 25 & 30 \\ 172 & 56 \\ 154 & 9 \\ 1 & - \\ 13.36 & 12.74 \\ 0.66 & 0.65\end{array}$

25

26

27

28

29

30

31

$\overline{\mathrm{X}}$

4

8

46

6

0.66

0.65

SD

1

10

50

27

16. 12

0. 32

\begin{tabular}{rr}
5 & 2 \\
298 & 21 \\
53 & 68 \\
\hline & 9
\end{tabular}

16.13

15.84

0. 38

0.59

1

$\begin{array}{rr} & 2 \\ 11 & 7 \\ 157 & 29 \\ 177 & 50 \\ 7 & 9 \\ 29.49 & 28.59 \\ 0.66 & 0.84\end{array}$




\section{I.A.A. MEKKEWY}

Table 7 : Cont.

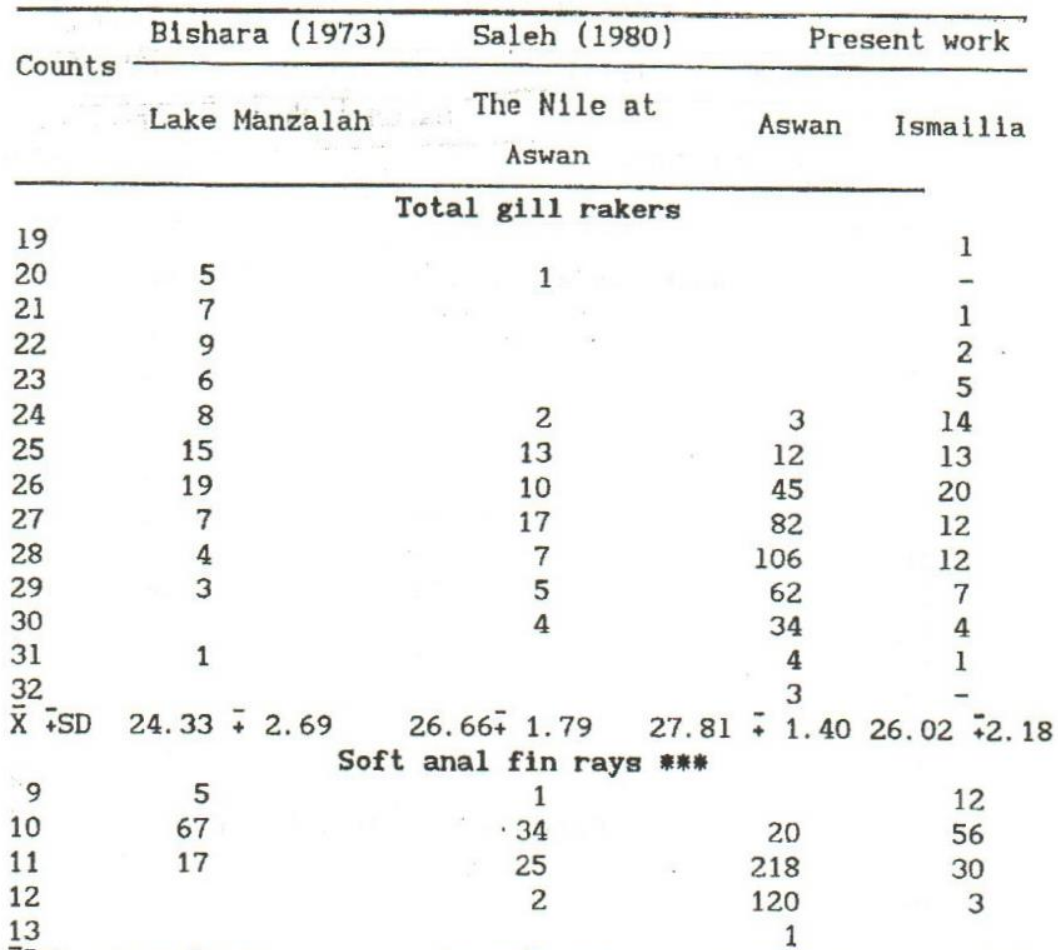

$\frac{13}{\mathrm{X}}+\mathrm{SD} \quad 10.13 \div 0.48$

10. $46 \div 0.59$

$11.28 \div 0.56$

10. $24 \overline{+0} .69$

Total vertebral counts
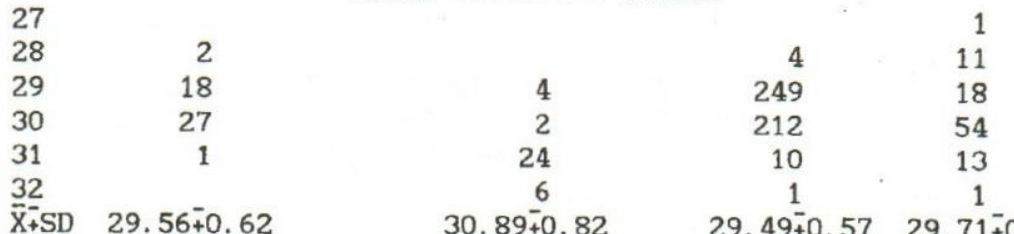

$\begin{array}{lll}30.89+0.82 & 29.49 \div 0.57 & 29.71 \div 0.91\end{array}$

Precaudal vertebral counts

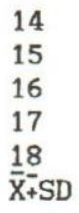

12

13

14

15

16

$\overline{\mathrm{X}}+\mathrm{SD}$

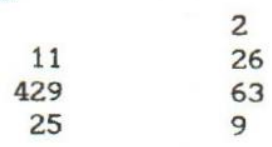

16. $86 \div 0.68$

15. $79+1.69$

15. $79 \div 0.62$

Caudal vertebral counts

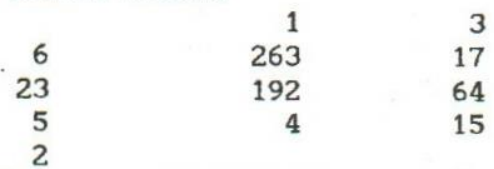

$14.08 \div 0.73 \quad 13.43 \div 0.52 \quad 13.92 \div 0.66$

Anal spines $=$ III 
INTRA-AND INTER-SPECIFTC VARIATTONS, MERISTIC CHARACTERISTICS, TILAPINE SPECIES OF EGYPT

Table 8 : Comparisons of some mesistic characters of Tilapia zillii in different Egyptian waters.

\begin{tabular}{|c|c|c|c|c|c|}
\hline \multirow{3}{*}{ Counts } & \multicolumn{2}{|c|}{ Bishara (1973) } & \multicolumn{2}{|c|}{ Saleh (1980) } & Present work \\
\hline & Lake & Lake & The Nile at & Lake & \multirow[t]{2}{*}{ Ismailia } \\
\hline & Manzalah & Qarun & Sohag & Qarun & \\
\hline
\end{tabular}

6

8

10

15

16

17

18

19

20

21

22

23

$\frac{24}{\bar{X}}$

SD

7

8

9

$\frac{10}{\bar{X}}$

SD

10

11

12

$\frac{13}{x}$

$\mathrm{X}$

XIV

$X V$
$X V I$
$\bar{x}$

SD

25

26

27

28

$\frac{2}{\bar{X}}$

SD

Upper pored lateral line scale counts

$\begin{array}{crr} & & 1 \\ & & 1 \\ & & 2 \\ & & 1 \\ 2 & & 2 \\ 2 & 2 & 1 \\ 10 & 4 & 5 \\ 31 & 13 & 20 \\ 28 & 14 & 8 \\ 8 & 5 & \\ 1 & - & \\ 1 & 1 & \\ 20.37 & 20.51 & 18.51 \\ 1.16 & 1.17 & 3.41\end{array}$

Soft anal fin rays

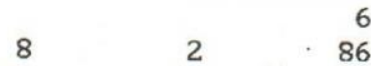

\section{6}

33

3

8.89

0.31

9. 01

8.22

0.25

0.52

Soft rays of dorsal fin

2

31

15

2

33

8,00

8.85

0.34

0.62

3. 41

2

29

61

18

3

36

$19 \quad 76$

6

11.83

18

76
12

11.96

12

0.56

0.85

11.76

0.65

$\begin{array}{cr}9 & 17 \\ 25 & 29 \\ 1 & 7 \\ 11.77 & 11.81 \\ 0.49 & 0.65\end{array}$

Dorsal $f$ in spines

3

72

23

15.20

$\begin{array}{rr}38 & 18 \\ 18 & 101\end{array}$

18

8

15. 32

14.92

0.47

0.45

$\begin{array}{cc} & 2 \\ 26 & 43 \\ 9 & 8 \\ 15.26 & 15.11 \\ 0.44 & 0.42\end{array}$

Dorsal fin spines and rays

$15.26 \quad 15.11$

0.48

6

9

23

61

15

23

37

75

9

27.29

26.69

26. 93

0.76

0.68

$\begin{array}{rc}5 & 15 \\ 24 & 28 \\ 6 & 9 \\ & 1 \\ 27.03 & 26.92 \\ 0.57 & 0.73\end{array}$




\section{I.A.A. MEKKEWY}

Table 8 : Cont.

\begin{tabular}{|c|c|c|c|c|c|}
\hline \multirow{3}{*}{ Counts } & \multicolumn{2}{|c|}{ Bishara (1973) } & Saleh (1980) & \multicolumn{2}{|c|}{ Present work } \\
\hline & Lake & Lake & The Nile at & Lake & Isma1lia \\
\hline & Manzalah & Qarun & Sohag & Qarun & \\
\hline \multicolumn{6}{|c|}{ Total vertebral counts } \\
\hline 26 & & 1 & & & \\
\hline 27 & 4 & 2 & 3 & & 7 \\
\hline 28 & 34 & 53 & 9 & 9 & 43 \\
\hline 29 & 26 & 6 & 58 & 27 & 5 \\
\hline 30 & & & 17 & 8 & 1 \\
\hline$\overline{\mathrm{X}}$ & 27.28 & 28.03 & 29.02 & 28.98 & 28.00 \\
\hline SD & 1. 45 & 0.44 & 0.66 & 0.63 & 0.54 \\
\hline \multicolumn{6}{|c|}{ Precaudal vertebral counts } \\
\hline 14 & & & 34 & 13 & 15 \\
\hline 15 & & & 38 & 17 & 38 \\
\hline 16 & & & 15 & 14 & 3 \\
\hline$\overline{\mathrm{x}}$ & & & 14.78 & 15.02 & 14.78 \\
\hline SD & & & 0.72 & 0.79 & 0.53 \\
\hline \multicolumn{6}{|c|}{ Caudal vertebral counts } \\
\hline 12 & & & & & 6 \\
\hline 13 & & & 11 & 13 & 34 \\
\hline 14 & & & 44 & 20 & 12 \\
\hline 15 & & & 32 & 11 & 2 \\
\hline$\overline{\mathrm{X}}$ & & & 14.24 & 13. 96 & 13. 19 \\
\hline SD & & & 0.66 & 0.74 & 0.68 \\
\hline \multicolumn{6}{|c|}{ Total gill rakers } \\
\hline 9 & & & 3 & & \\
\hline 10 & 12 & & 6 & 11 & 1 \\
\hline 11 & 18 & & 15 & 24 & 3 \\
\hline 12 & 20 & & 37 & 15 & 18 \\
\hline 13 & 30 & & 42 & 10 & 20 \\
\hline 14 & 7 & & 23 & 3 & 11 \\
\hline 15 & 6 & & 9 & & 1 \\
\hline 16 & & & 5 & & \\
\hline 17 & & & 1 & & \\
\hline 20 & & & 1 & & \\
\hline$\overline{\mathrm{x}}$ & 12. 21 & & 12.79 & 11.52 & 12.74 \\
\hline SD & 1.37 & & 1.60 & 1.11 & 0.97 \\
\hline
\end{tabular}


Table 9 : Comparisons of total vertebral counts of 0. niloticus in different waters.

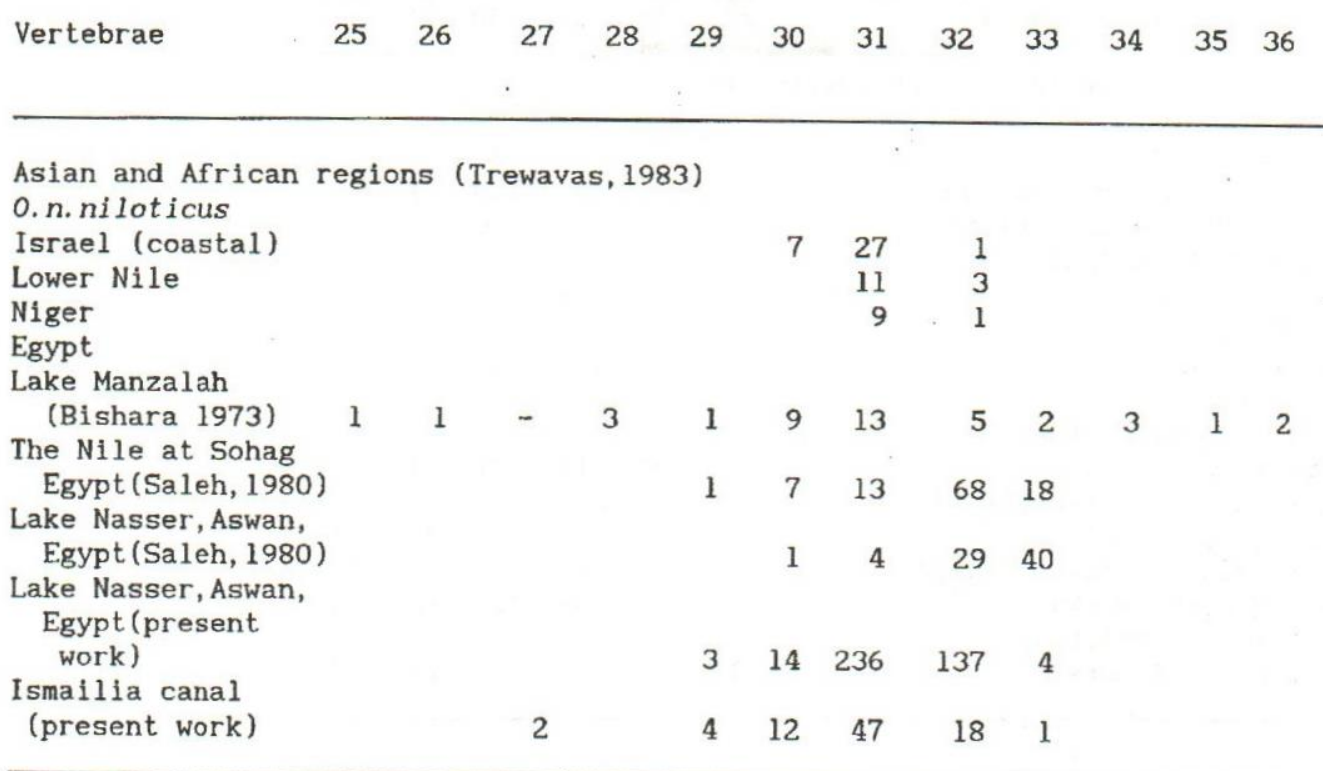

Table 10 : Comparisons of some meristic characters of 0 . niloticus in different waters.

Dorsal fin spines Dorsal fin spines \& rays XV XVI XVII XVIII $27 \quad 28 \quad 29 \quad 30 \quad 3132 \quad 33$

Africa (Trewavas, 1983)

o. n. niloticus

West Africa

R. Yarkon

Nile

Egypt

Lake Manzalah

(Bishara, 1973)

Lake Nasser, Aswan

(present work)

Ismailia canal

(present work)

$\begin{array}{rrrrrrrr}1 & 2 & 16 & 5 & 3 & 19 & 4 & \\ & 6 & 22 & 1 & 2 & 17 & 10 & \\ & 2 & 33 & 6 & 4 & 22 & 14 & 1\end{array}$

$\begin{array}{lllllllll}1 & 26 & 72 & 7 & 3 & 8 & 53 & 39 & 3\end{array}$

$11230 \quad 99$

$\begin{array}{llllll}1 & 11 & 142 & 161 & 23 & 2\end{array}$

$\begin{array}{lllllllll}5 & 11 & 57 & 11 & 4 & 4 & 29 & 35 & 12\end{array}$ 


\section{I.A.A. MEKKEWY}

Table 11 : Comparisons of total vertebral counts of $S$. galilaeus in different waters.

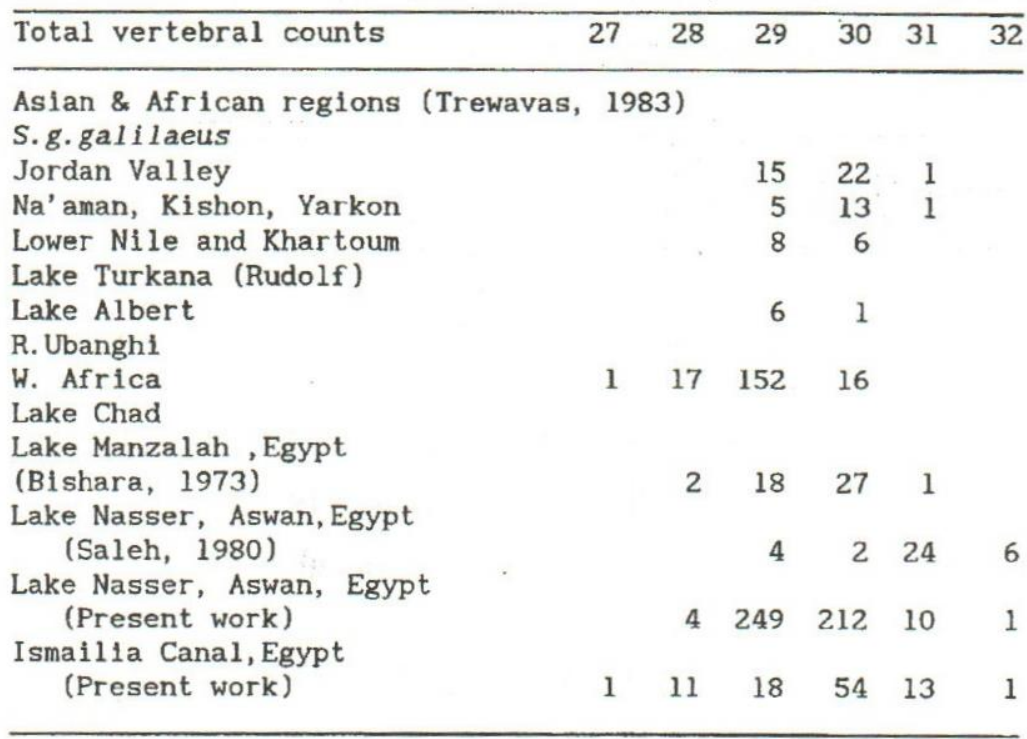

Table 12 : Comparisons of some meristic characters of S. galilaeus in different waters.

Dorsal fin spines Dorsal fin spines \& rays Soft anal fin rays $\begin{array}{llllllllllllllll}\text { XIV } & \text { XV } & \text { XVI } & \text { XVII } & 24 & 26 & 27 & 28 & 29 & 30 & 31 & 9 & 10 & 11 & 12 & 13\end{array}$

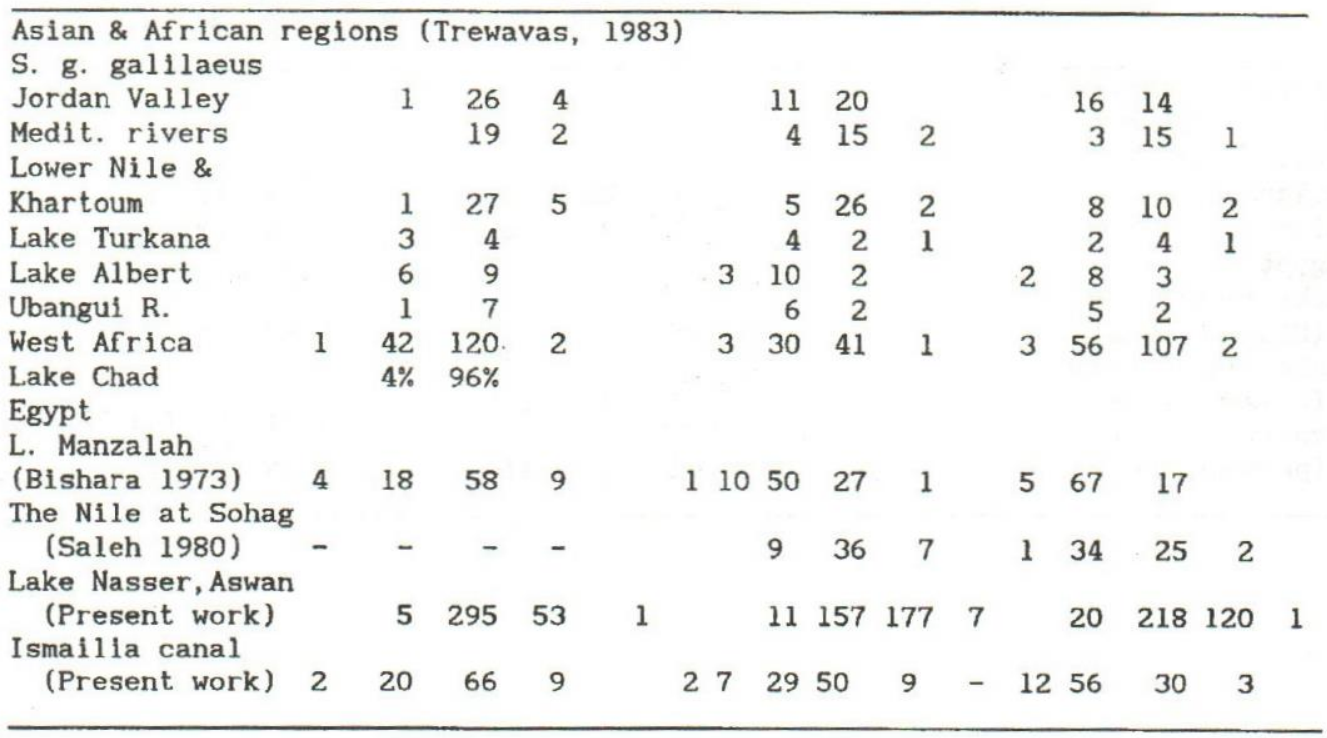


i)

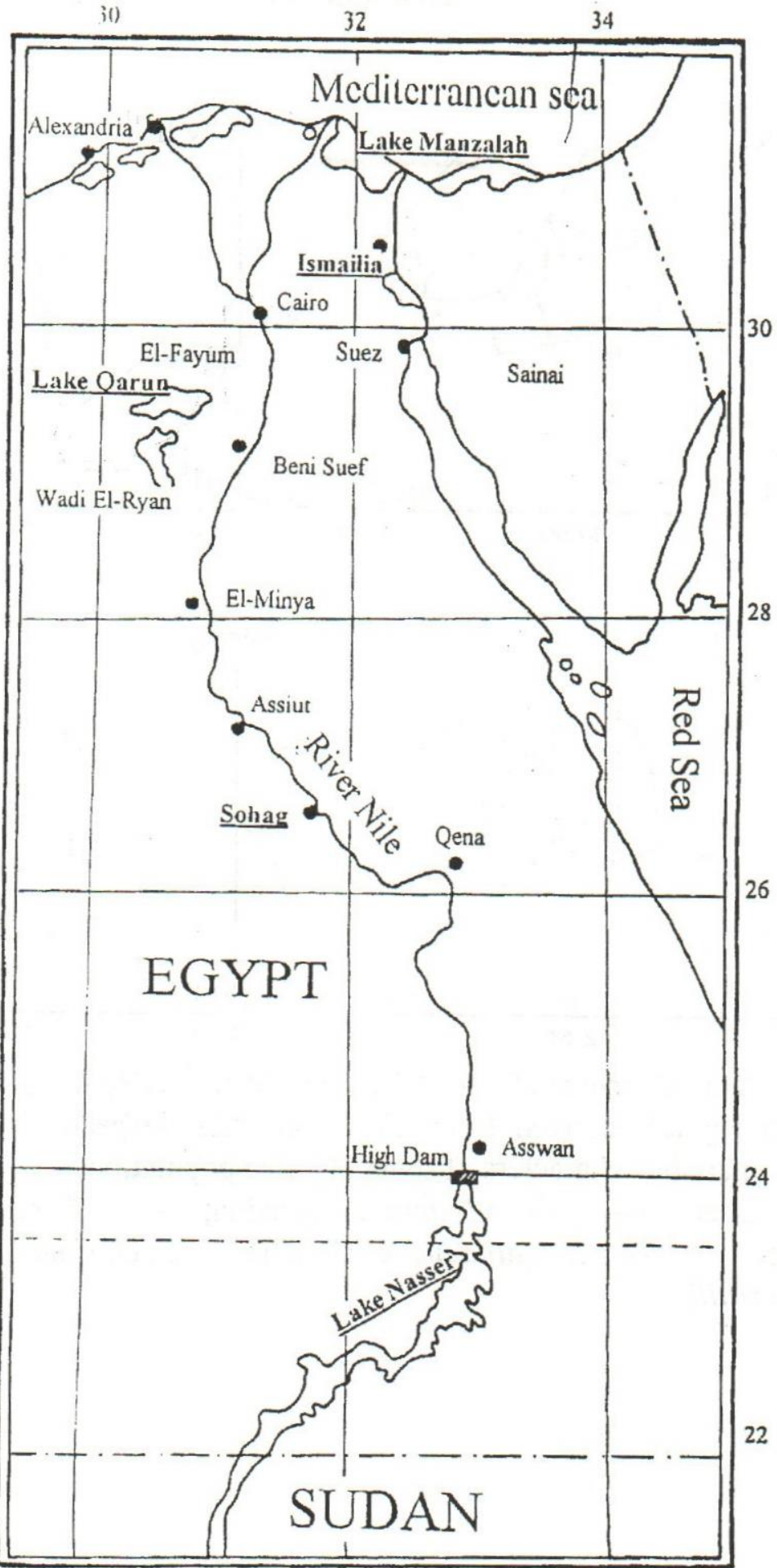

Fig. 1: The different Egyptian localities considered in the present investigation (underlined). 


\section{I.A.A. MEKKEWY}
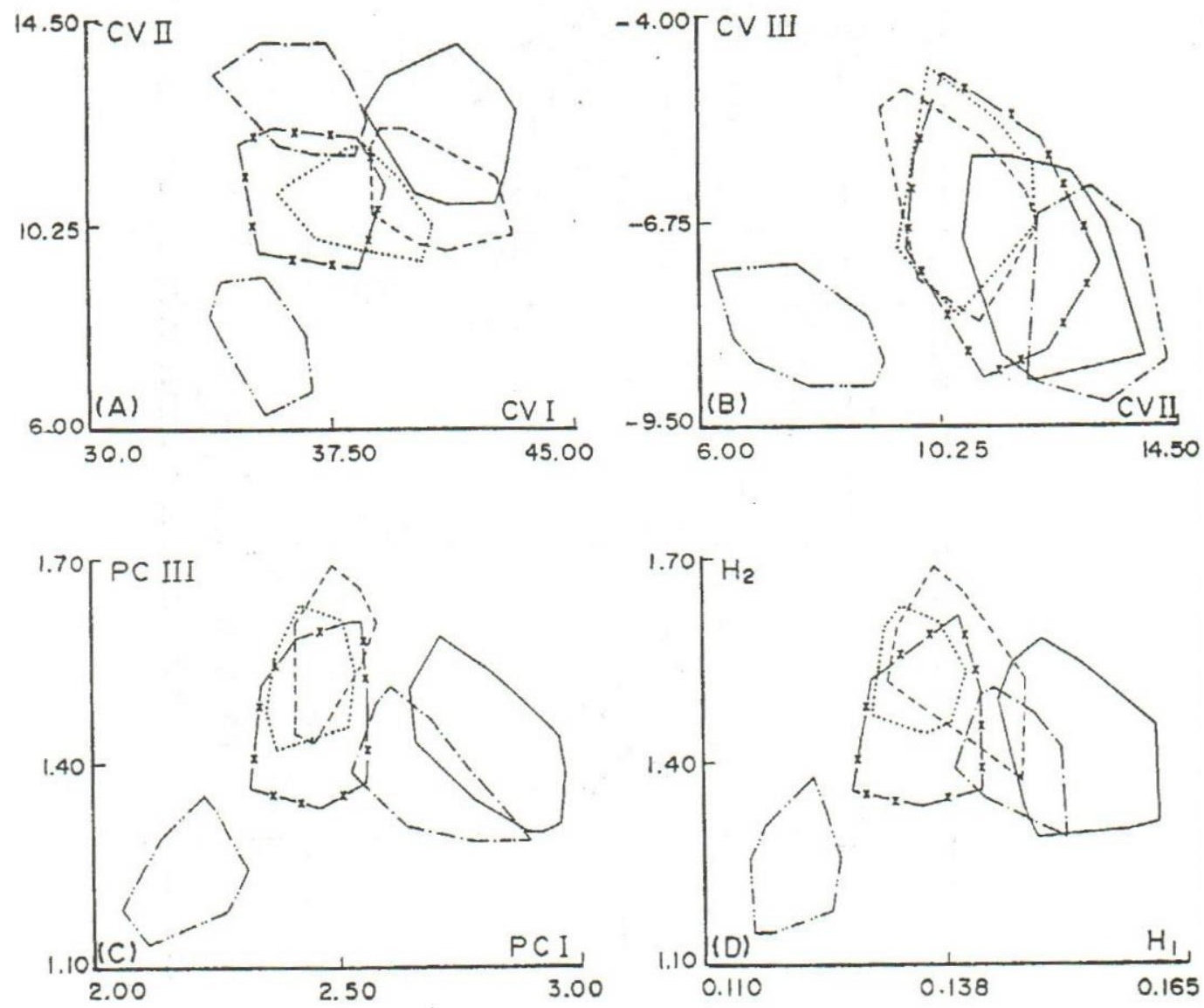

Fig. 2 :Plots of scores of CVI, CVII and CVIII (A\&B) and of PCI, PCIII(C), $\mathrm{H}_{1}$ and $\mathrm{H}_{2}$ (D) derived from CVA and PCA respectively carried out on certain meristic characters of some tilapine populations $(-$, O. niloticus of Lake Nasser; ----, O. niloticus of Ismailia; --_-, S. galilaeus of Lake Nasser; $\quad-\mathrm{x}-\mathrm{x}-$, S. galilaeus of Ismailia; ........, O. ismailiaensis; -....-, Tilapia zillii). 
INTRA-AND INTER-SPECIFTC VARIATTONS, MERISTIC CHARACTERISTICS, TILAPINE SPECIES OF EGYPT

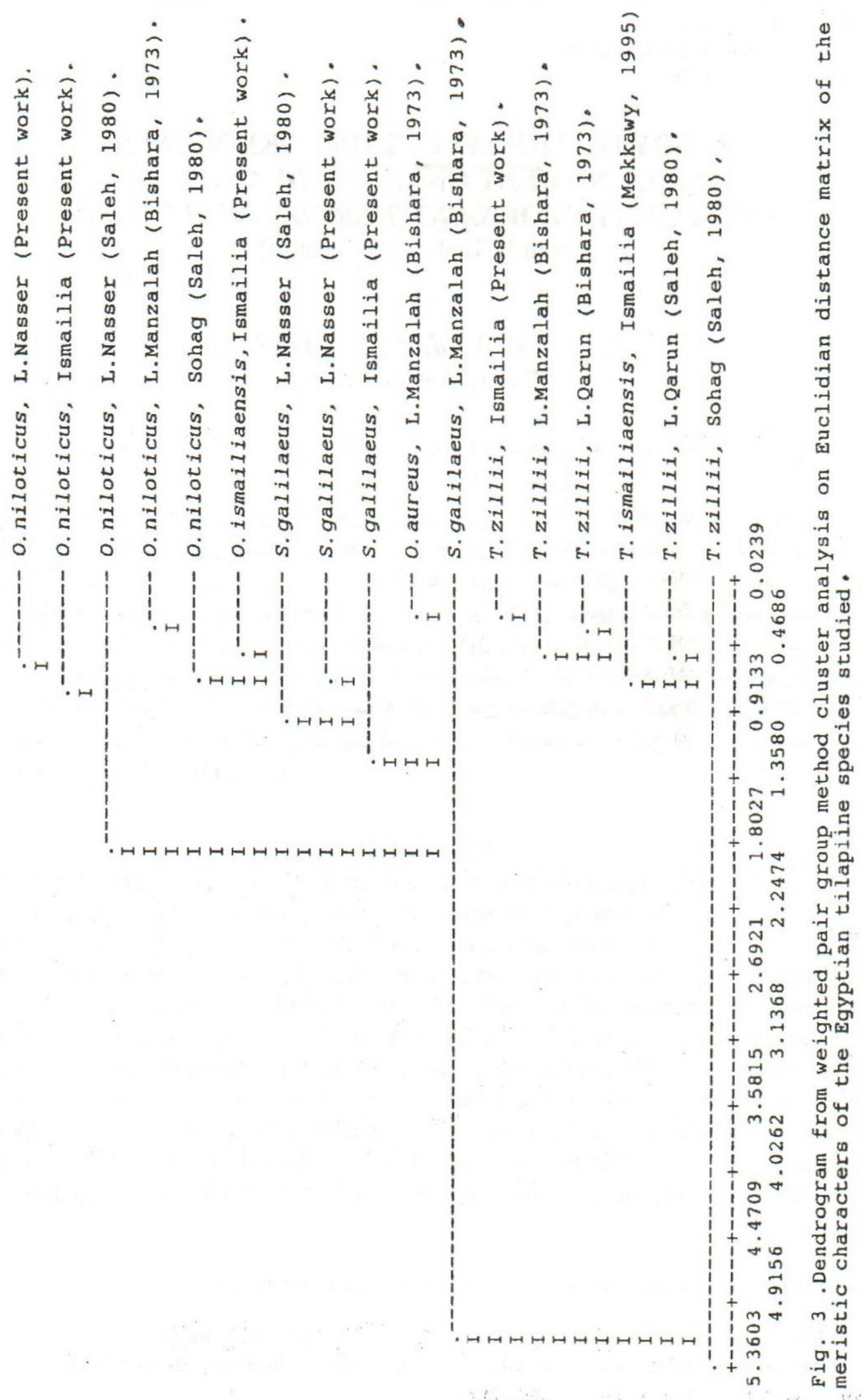

